\title{
Diverse Consequences in Liver Injury in Mice with Different Autophagy Functional Status Treated with Alcohol
}

\author{
Shengmin Yan, ${ }^{*}$ Jun Zhou, ${ }^{* \dagger}$ Xiaoyun Chen, ${ }^{*}$ Zheng Dong, ${ }^{\ddagger \S}$ and Xiao-Ming Yin ${ }^{* \ddagger}$
}

\begin{abstract}
From the Department of Pathology and Laboratory Medicine, * Indiana University School of Medicine, Indianapolis, Indiana; the Departments of Minimal Invasive Surgery ${ }^{\dagger}$ and Nephrology, ${ }^{\ddagger}$ The Second Xiangya Hospital, Central South University, Changsha, China; and the Department of Cell Biology and Anatomy, ${ }^{\S}$ Medical College of Georgia and Charlie Norwood Veterans Affairs Medical Center, Augusta, Georgia
\end{abstract}

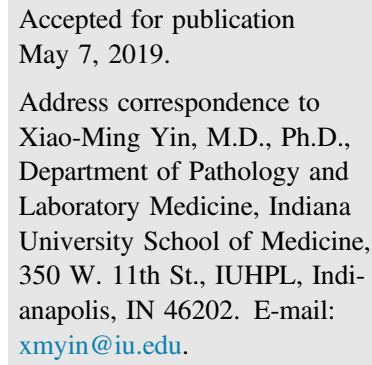

\begin{abstract}
Alcoholic fatty liver disease is often complicated by other pathologic insults, such as viral infection or high-fat diet. Autophagy plays a homeostatic role in the liver but can be compromised by alcohol, highfat diet, or viral infection, which in turn affects the disease process caused by these etiologies. To understand the full impact of autophagy modulation on alcohol-induced liver injury, several genetic models of autophagy deficiency, which have different levels of functional alterations, were examined after acute binge or chronic-plus-binge treatment. Mice given alcohol with either mode and induced with deficiency in liver-specific Atg7 shortly after the induction of Atg7 deletion had elevated liver injury, indicating the protective role of autophagy. Constitutive hepatic Atg7-deficient mice, in which Atg7 was deleted in embryos, were more susceptible with chronic-plus-binge but not with acute alcohol treatment. Constitutive hepatic Atg5-deficient mice, in which Atg5 was deleted in embryos, were more susceptible with acute alcohol treatment, but liver injury was unexpectedly improved with the chronicplus-binge regimen. A prolonged autophagy deficiency may complicate the hepatic response to alcohol treatment, likely in part due to endogenous liver injury. The complexity of the relationship between autophagy deficiency and alcohol-induced liver injury can thus be affected by the timing of autophagy dysfunction, the exact autophagy gene being affected, and the alcohol treatment regimen. (Am J Pathol 2019, 189: 1744-1762; https://doi.org/10.1016/j.ajpath.2019.05.011)
\end{abstract}

The liver plays a crucial role in metabolism in the body. ${ }^{1}$ When metabolic homeostasis is disturbed in the liver, fatty liver disease (FLD), which is characterized by steatosis, inflammation, and fibrosis, can occur. FLD can be subclassified as being caused by excessive alcohol intake (alcoholic fatty liver disease; AFLD) or by any non-alcoholrelated etiology (nonalcoholic fatty liver disease; NAFLD). ${ }^{2}$

Autophagy is an evolutionarily conserved cellular degradation process that involves the delivery of cytoplasmic cargo (macromolecules or organelles) to the lysosome. ${ }^{3}$ Three types of autophagy have been defined: macroautophagy, microautophagy, and chaperone-mediated autophagy. Macroautophagy is quantitatively the most active form of autophagy and is referred to hereafter as autophagy. In macroautophagy, cytosolic materials are sequestered inside the autophagosome, and transported to, and degraded in, the lysosome. ${ }^{5}$ Autophagy occurs at the basal level in the liver and can be further enhanced under conditions of stress. It can play an important role in the maintenance of normal liver function and in the pathogenesis of various liver diseases. ${ }^{6,7}$ In particular, autophagy could be activated or depressed in such common liver diseases as AFLD,$^{8-12}$ NAFLD, ${ }^{13-15}$ and hepatitis viral infection. $^{16-19}$

The pathologic processes of AFLD are considered to be related to oxidative stress caused by the accumulation of acetaldehyde, increased $\mathrm{NADH} / \mathrm{NAD}^{+}$ratio, or generation of reactive oxidative species. ${ }^{20-22}$ During the progress of

Supported in part by NIH grants R21AA-021450 (X-M.Y) and R01AA021751 (X-M.Y).

Disclosures: None declared. 
AFLD, oxidative stress may induce functional and structural mitochondrial changes that may affect oxidative phosphorylation, increase mitochondrial DNA damage, and alter mitochondrial protein profiles. ${ }^{23-28}$ Increased reactive oxygen species, together with alcoholic steatosis, lead to lipid peroxidation that can further enhance oxidative damage in AFLD. ${ }^{29}$ As shown in previous studies, the effects of autophagy can vary at different pathologic stages of AFLD. ${ }^{8,9,12,15,30}$ Autophagy is activated in the liver in vivo and in cultured primary hepatocytes after acute alcohol treatment. ${ }^{8,9,30}$ This activation requires alcohol metabolism, and is mediated by reactive oxygen species and several signaling pathways. Acetaldehyde, a major alcohol metabolite and a pro-oxidant, has been implicated in the induction of autophagy. ${ }^{31}$ Meanwhile, alcohol-induced autophagy can be suppressed by antioxidants, such as $N$-acetyl cysteine. ${ }^{8,32}$ In addition, alcohol treatment alters the mammalian target of rapamycin, 5' AMP-activated protein kinase, and/or forkhead box O3a signaling pathway, ${ }^{33-35}$ which can contribute to changes in the autophagy process. Other autophagy stimulators, including alcohol-induced endoplasmic reticulum stress, proteasome inhibition, and minerals such as zinc, are also implicated in the dynamics of autophagy after alcohol treatment. ${ }^{36-38}$

Interestingly, autophagy may be suppressed in chronic alcohol treatment or in other liver diseases. When mice were fed with a Lieber-DeCarli diet for 4 weeks, hepatic autophagy was stimulated at a lower dose of alcohol (accounting for $29 \%$ of the caloric need) but was inhibited at a higher alcohol dose (accounting for $36 \%$ of the caloric need). ${ }^{15}$ The suppression of autophagy by long-term alcohol use suggests that the promotion of autophagy can improve the condition. The cause of the autophagy suppression may include decreases in both the amount and the functioning of lysosomes, which were found in long-term alcohol-treated rat livers. ${ }^{10,11,39}$ Indeed, the findings from a recent study suggest that the level of transcription factor EB, which plays a crucial role in lysosomal biogenesis and autophagy, was decreased in the livers of mice given alcohol diet and in patients with alcohol-induced hepatitis. ${ }^{12}$ Disruption of hepatic transcription factor EB enhanced alcohol-induced liver injury in mice, but the increase in transcription factor EB level led to reduced alcohol-induced liver injury through elevated lysosomal biogenesis and mitochondrial bioenergetics. $^{12}$

Nonetheless, the assessment of the contribution of autophagy to alcohol-induced liver injury had been mainly conducted through acute pharmacologic manipulation or acute knockout of certain autophagy-related genes. The impact of chronic autophagy deficiency on alcoholic liver injury has not been assessed. This effect may be important as ALDs are often complicated by other disease-causing factors, such as viral infection or high-fat diet, which can compromise autophagy. The present study thus used several genetic models of autophagy deficiency to assess the effects of alcohol in different autophagy functional statuses. The findings suggest that the complicated interaction between alcohol and autophagy in liver injury can be affected by the timing of autophagy dysfunction, the exact autophagy gene being affected, and the alcohol treatment regimen.

\section{Materials and Methods}

\section{Mice}

Atg $5^{\mathrm{F} / \mathrm{F}}$ mice $(B 6.129 \text { S-Atg5tm1Myok) })^{40}$ and $\operatorname{Atg} 7^{\mathrm{F} / \mathrm{F}}$ mice have been reported in previous studies. Atg $5^{\Delta \text { hep }}$ and $\operatorname{Atg} 7^{\Delta \text { hep }}$ mice were generated by crossing $\operatorname{Atg} 5^{\mathrm{F} / \mathrm{F}}$ or $\operatorname{Atg} 7^{\mathrm{F} / \mathrm{F}}$ with Alb:Cre transgenic mice, respectively (The Jackson Laboratory, Bar Harbor, ME). The inducible liver-specific Atg7-deficient mice $\left(A t g 7^{\Delta h e p-E R T 2}\right)$ were generated by crossing $A t g 7^{\text {F/F }}$ mice with Alb:Cre-ER ${ }^{\mathrm{T} 2}$ mice. ${ }^{42}$ The deletion of Atg7 was induced by the administration of tamoxifen $(6 \mathrm{mg} /$ day s.c., for 2 days). Mice were maintained on a 12-hour dark/light cycle with free access to food and water. Both male and female mice were used in the studies. Age- and sex-matched mice were randomly assigned to the treatment or control group.

Table 1 Antibody List

\begin{tabular}{|c|c|c|c|}
\hline Antibody name & Company & Catalog number & Host \\
\hline ACTIN (8H10D10) & Cell Signaling Technology (Beverly, MA) & 3700 & Mouse \\
\hline $\mathrm{ADH}$ & Santa Cruz Biotechnology (Dallas, TX) & sc-133207 & Mouse \\
\hline ALDH1/2 & Santa Cruz Biotechnology & sc-166362 & Mouse \\
\hline ATG12 & Cell Signaling Technology & 2011 & Rabbit \\
\hline ATG7 & Cell Signaling Technology & 2631 & Rabbit \\
\hline CK19 & Developmental Studies Hybridoma Bank (University of Iowa, Iowa City, IA) & TROMA-III & Rat \\
\hline $\mathrm{LC} 3 \mathrm{~B}$ & Sigma-Aldrich (St. Louis, M0) & L7543 & Rabbit \\
\hline NQ01 & Abcam (Cambridge, MA) & ab34173 & Rabbit \\
\hline SQSTM1/p62 & Abnova (Taipei, Taiwan) & H00008878-M01 & Mouse \\
\hline$\alpha$-Smooth muscle actin & Thermo Fisher Scientific (Waltham, MA) & PA5-19465 & Rabbit \\
\hline
\end{tabular}

Adh, alcohol dehydrogenase; Aldh, aldehyde dehydrogenase; ATG, autophagy-related protein; CK, cytokeratin; CYP, cytochrome P450; Gapdh, glyceraldehyde phosphate dehydrogenase; LC, microtubule-associated protein 1A/1B-light chain; NQ0, NAD(P)H quinone dehydrogenase; Sqstm, sequestosome. 
Table 2 Primer List

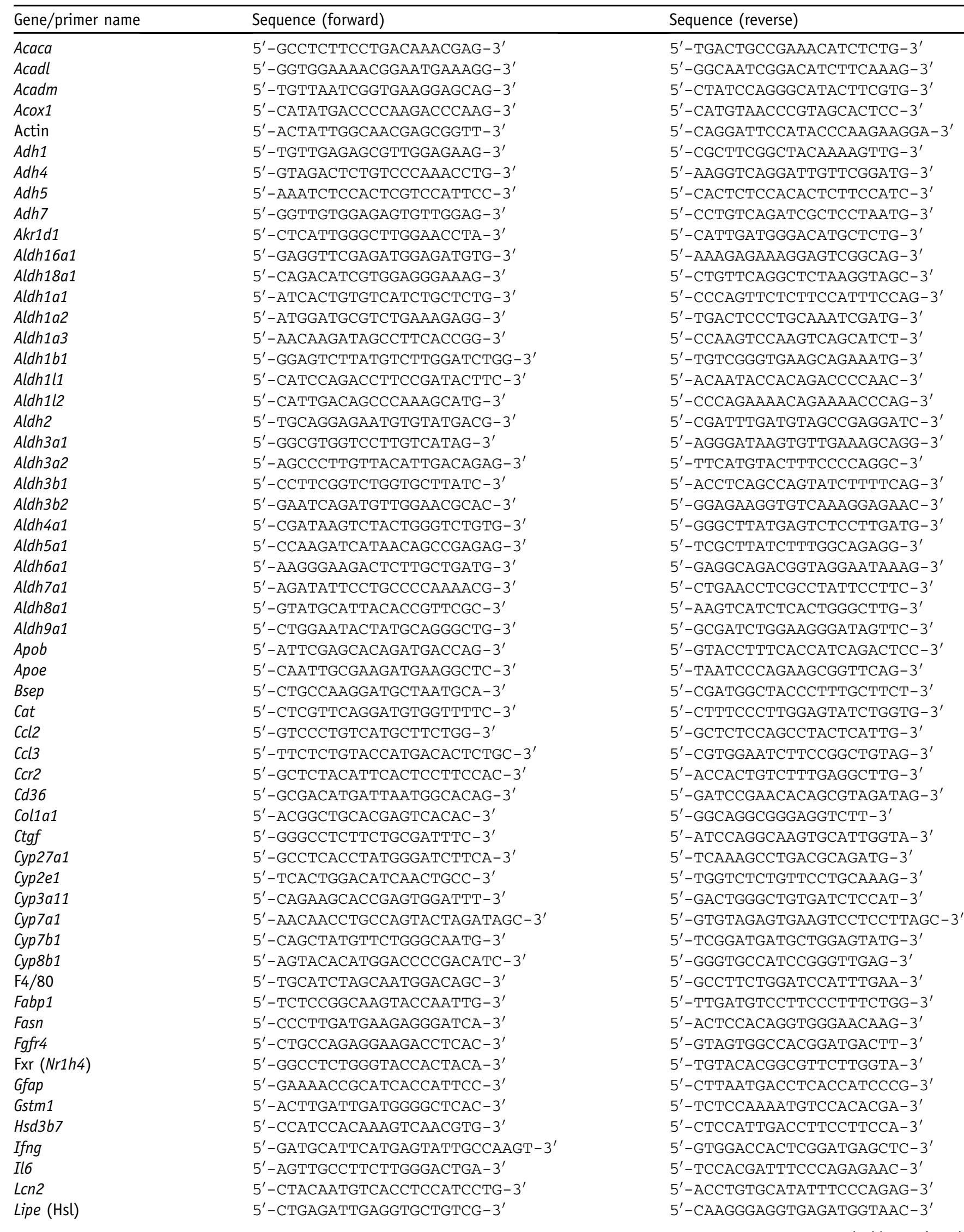

(table continues) 
Table 2 (continued)

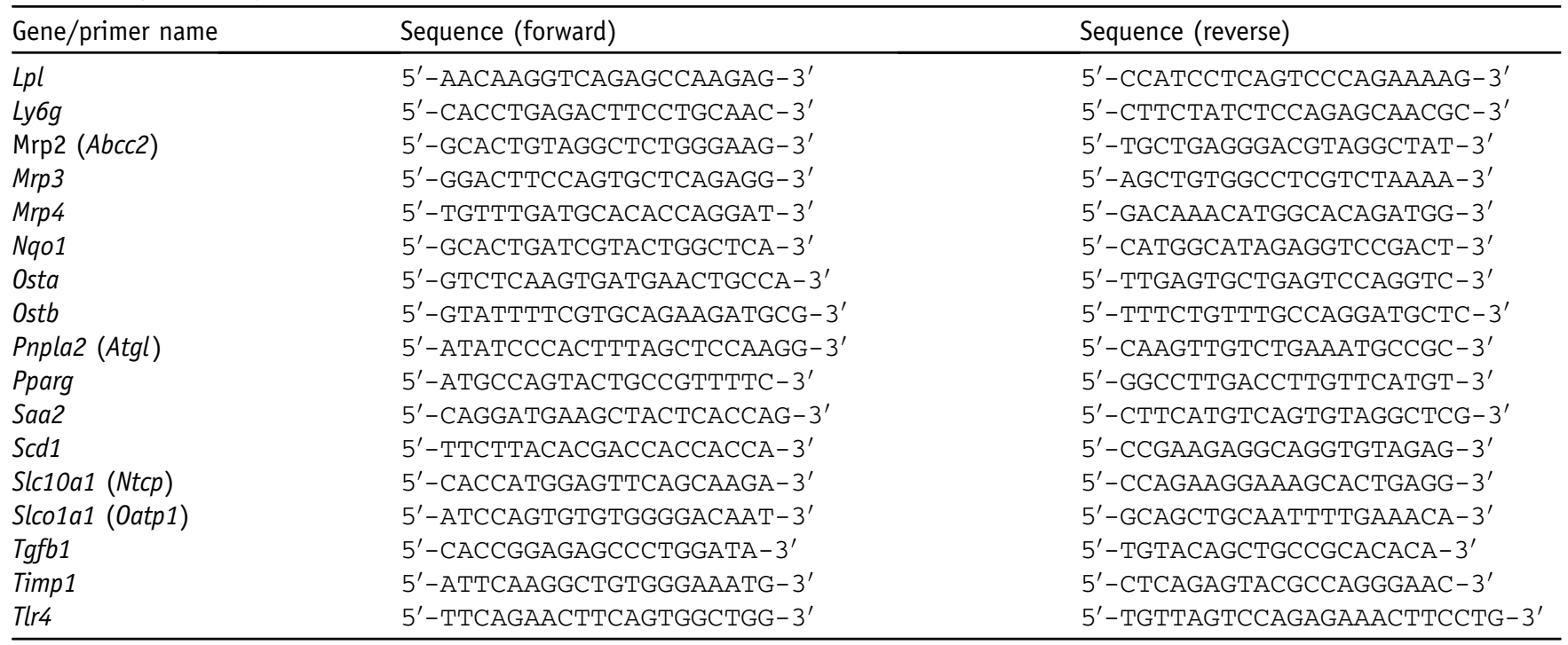

Fxr, farnesoid X receptor; Hsl, hormone-sensitive lipase; Mrp, multidrug-resistance protein.

\section{Animal Models}

Acute alcohol binge was conducted as previously described. ${ }^{8}$ After 6 hours of fasting, mice were given 31.5\% $(\mathrm{v} / \mathrm{v})$ alcohol by gavage at a total accumulative dosage of 5 $\mathrm{g} / \mathrm{kg}$ of body weight in four equally divided doses at 20minute intervals. $\operatorname{Atg} 7^{\mathrm{Ahep}-\mathrm{ERT} 2}$ and control $\operatorname{Atg} 7^{\mathrm{F} / \mathrm{F}}$ mice were injected with tamoxifen $(6 \mathrm{mg} /$ day s.c., for 2 days $) 7$ days before they were given acute alcohol binge as described in the previous sentence or as indicated in the figure legends. The control mice were given the same volume of water.

The chronic-plus-binge model was conducted as previously described. ${ }^{43}$ Mice were acclimated with liquid control food for 5 days. The alcohol-treated groups were then given a liquid diet containing 5\% (w/v) alcohol for 10 days. Pairfed groups were given the same volume of control food. In the early morning of day 11 , mice in the alcohol-treated groups were given a single dose of $31.5 \%(\mathrm{v} / \mathrm{v})$ alcohol $(5$ $\mathrm{g} / \mathrm{kg}$ of body weight) by gavage. Pair-fed mice were given an isocaloric dose of dextrin maltose by gavage. After 9 hours, the mice were euthanized, and blood and tissue samples were collected.

The protocols of all animal experiments were approved by the Institutional Animal Care and Use Committee of Indiana University (Indianapolis, Indiana).

\section{Antibodies and Chemicals}

Antibodies and PCR primers used in this study are listed in Tables 1 and 2, respectively. Tamoxifen (Sigma-Aldrich, St. Louis, MO) was diluted in corn oil. Alcohol (190 proof; Decon Labs, King of Prussia, PA) was diluted in water or added to a formulated liquid diet. ${ }^{43}$ Bio-Serv Lieber-DeCarli '82 Shake and Pour alcohol liquid diet (catalog number
F1258SP; Fisher Scientific, Pittsburgh, PA) was used as the alcohol diet. Bio-Serv Lieber-DeCarli '82 Shake and Pour control liquid diet (catalog number F1259SP; Fisher Scientific) was used as the control diet.

\section{Serum Biochemistry Analysis}

Serum levels of alanine aminotransferase (ALT), aspartate aminotransferase (AST), alkaline phosphatase (ALP), triglycerides (TG), and total cholesterol (TCHO) were measured using kits from Pointe Scientific (Canton, MI) according to the manufacturer's protocol. Serum total bile acids (TBA) were measured using a TBA assay kit from Diazyme Laboratories, Inc. (Poway, CA).

\section{Hepatic Lipid Content Analysis}

A piece of liver tissue was weighed and incubated in $1 \mathrm{~mL}$ of chloroform-methanol mix $(2: 1, \mathrm{v} / \mathrm{v})$ with shaking for 1 hour at room temperature to extract lipids. After the addition of $200 \mu \mathrm{L}$ of water, samples were vortexed and centrifuged at $3000 \times g$ for 5 minutes. The lower lipid phase was collected and dried at room temperature in a chemical hood. The lipid pellet was resuspended in $60 \mu \mathrm{L}$ of tert-butanol and $40 \mu \mathrm{L}$ of a Triton X-114 methanol $(2: 1, \mathrm{v} / \mathrm{v})$ mix. TG and TCHO contents were measured using respective kits from Pointe Scientific. The lipid contents hence were normalized with the tissue weight.

\section{Hepatic TBA Content Analysis}

Liver tissue samples $(100 \mathrm{mg})$ were homogenized in $1 \mathrm{~mL}$ of $90 \%$ alcohol and incubated at $55^{\circ} \mathrm{C}$ overnight. The lysates were centrifuged at $9600 \times g$ for 10 minutes. The supernatants were collected and measured for TBA 

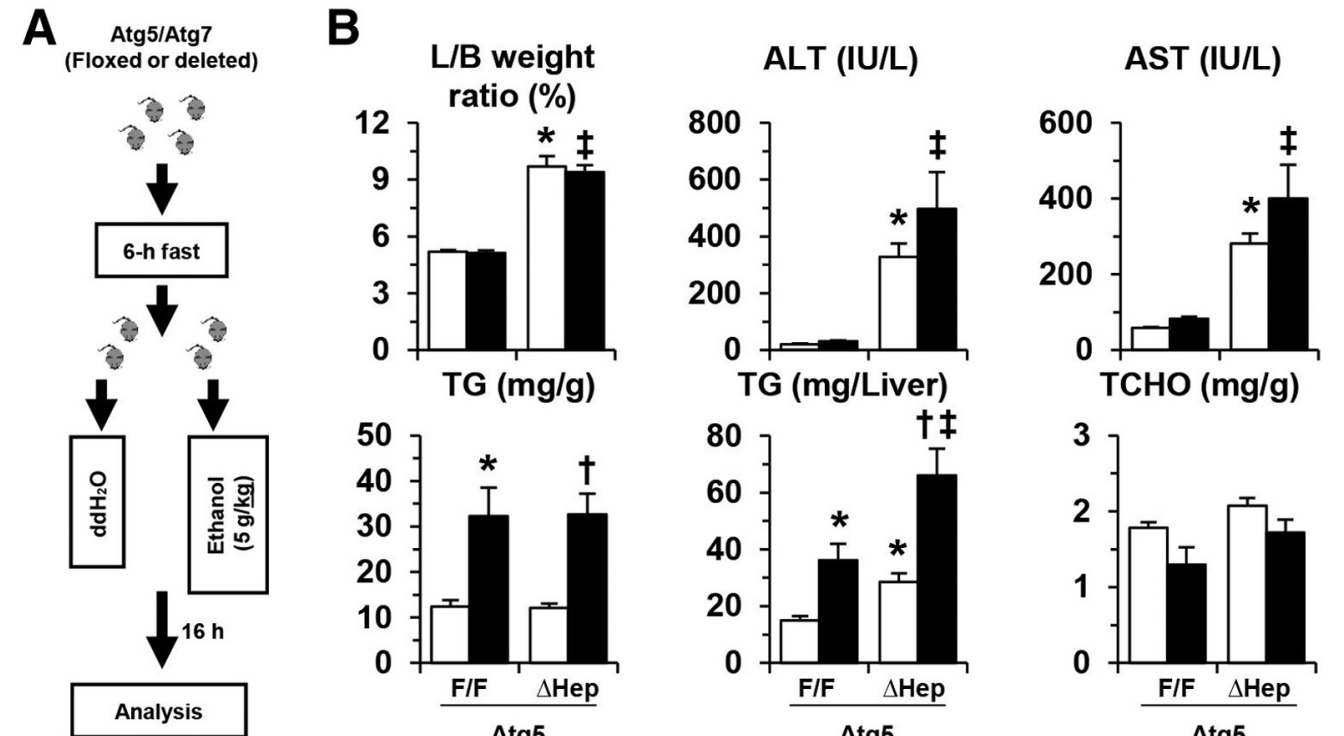

$$
\begin{gathered}
\text { Control } \square \text { Ethanol } \\
\text { ALP (IU/L) }
\end{gathered}
$$
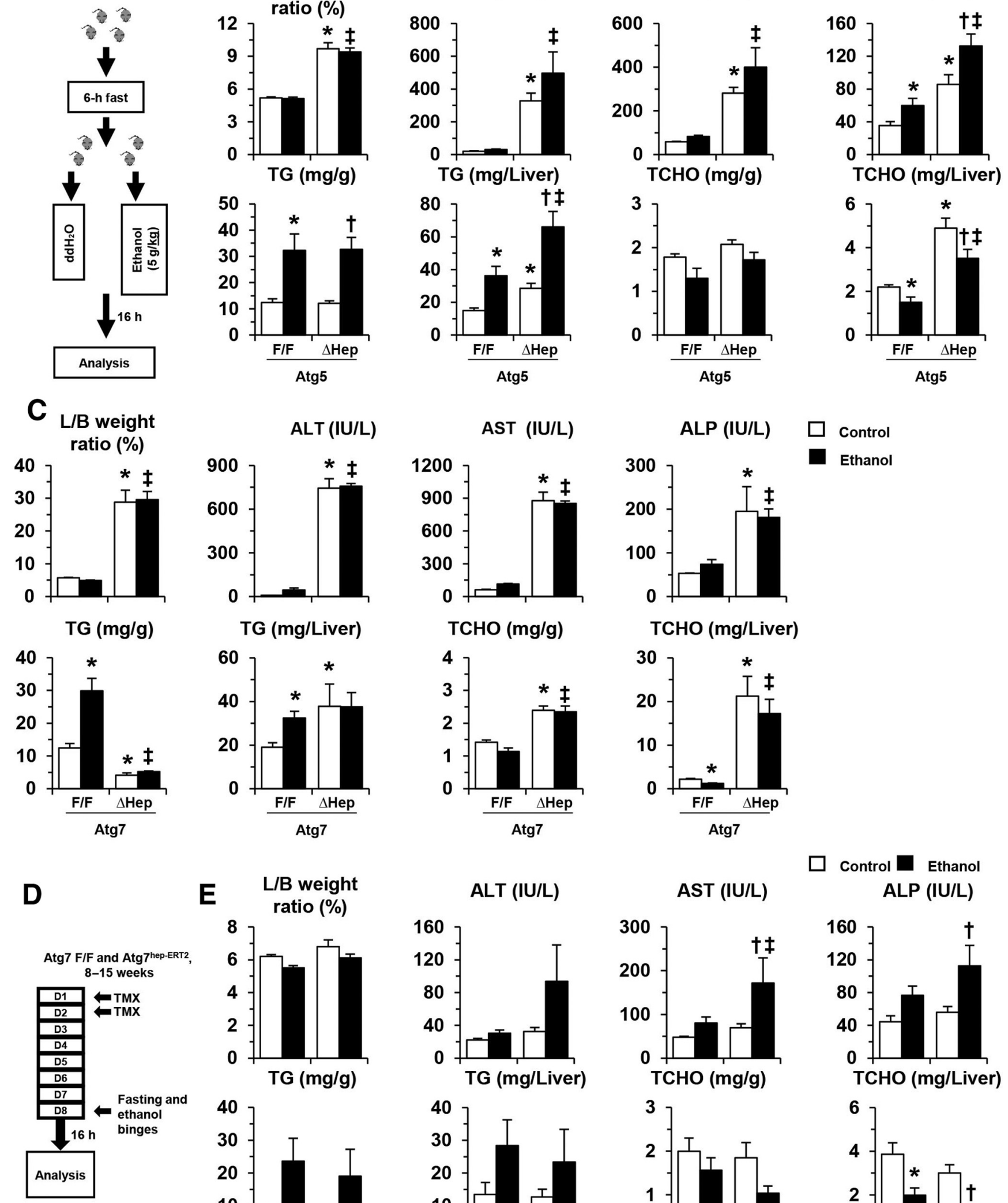

ALT (IU/L)
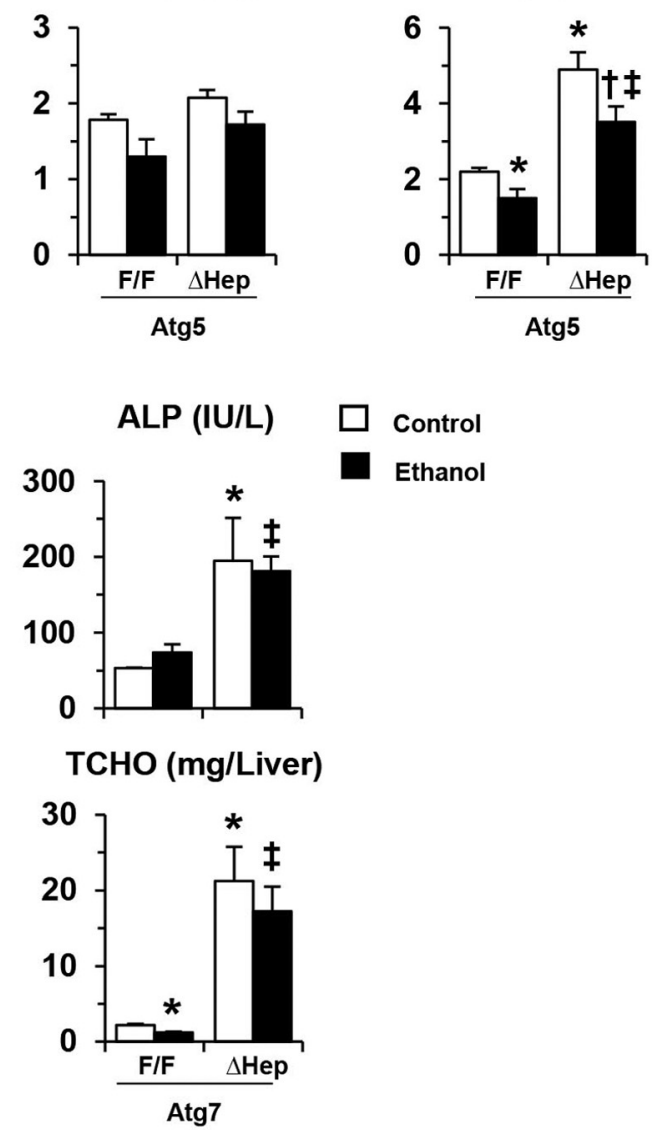
concentration using a TBA assay kit from Diazyme Laboratories, Inc.

\section{Immunoblotting Analysis}

The liver samples were homogenized in the radio immunoprecipitation assay buffer containing a protease cocktail. Supernatant was collected after centrifugation at 13,800 $\times g$ for 12 minutes. Protein concentration was determined using a Pierce BCA protein assay kit (Thermo Fisher Scientific, Waltham, MA). The proteins were separated on SDS-PAGE. Proteins were transferred onto polyvinylidene fluoride membranes, which were then blocked with $5 \%$ bovine serum albumin or $5 \%$ skim milk for 1 hour at room temperature. Membranes were incubated overnight with the appropriate primary antibody and then washed with Tris-buffered saline and $0.1 \%$ Tween 20 before being incubated with the horseradish peroxidase-coupled secondary antibodies at room temperature. Protein bands were detected using an enhanced chemiluminescence kit (Thermo Fisher Scientific/Pierce). The images were taken digitally with the ChemiDoc Imaging System (Bio-Rad, Hercules, CA). Densitometry was measured using the companion software, Image Lab software version 6.0.1 (Bio-Rad), and the values were normalized to that of $\beta$-actin or glyceraldehyde phosphate dehydrogenase, which were then converted to fold changes of the control.

\section{RNA Isolation and Real-Time Quantitative PCR Analysis}

Total RNA was prepared from liver samples using GeneJET RNA Purification Kit (Thermo Fisher Scientific, Grand Island, NY) according to the manufacturer's protocols. cDNA was synthesized using oligo dT primers and an M-MLV Reverse Transcriptase System (Life Technologies, Carlsbad, CA). Real-time quantitative PCR analysis was performed on an Applied Biosystems 7500 Real-Time PCR System (Life Technologies) using SYBR Green master mixes (Life Technologies). All real-time quantitative PCR results were normalized to the level of $\beta$-actin, and the gene expression was calculated using the $2_{\tau}^{-\Delta \Delta C}$ method.

\section{Histologic Study}

Liver samples were harvested, rinsed with phosphatebuffered saline, and fixed in $10 \%$ formalin overnight. Samples were further fixed in $70 \%$ alcohol and processed as paraffin-embedded blocks. The paraffin-embedded tissues were sectioned and stained with hematoxylin and eosin,
anti-F4/80, or Masson's trichrome C. Photomicrographs were taken using an Eclipse E200 light microscope (Nikon Instruments, Melville, NY) equipped with a SPOT RT Slider color digital camera (Diagnostic Instruments, Inc., Sterling Heights, MI). Area with positive F4/80 or Masson's trichrome $\mathrm{C}$ staining were quantified using ImageJ software version 1.51 (NIH, Bethesda, MD; http://imagej.nih.gov/ij); at least four random fields of each section from each mouse liver were used for quantification.

\section{Immunofluorescence Microscopy}

Paraffin sections were subjected to antigen retrieval treatment using the citrate buffer $(0.01 \mathrm{~mol} / \mathrm{L}, \mathrm{pH} 6.0)$ after deparaffinization. Slides were blocked with 5\% goat serum in phosphate-buffered saline containing $0.1 \%$ Triton $\mathrm{X}$ (PBS-Tx) for 1 hour and then incubated with primary antibodies diluted in $1 \%$ bovine serum albumin/PBS-Tx overnight at $4^{\circ} \mathrm{C}$. Sections were washed with phosphatebuffered saline, followed by incubation with fluorochromeconjugated secondary antibodies. Hoechst 33342 was used for nucleus staining. Images were obtained using as Eclipse TE 200 epi-immunofluorescence microscope (Nikon) and the companion NIS-Elements software version AR3.2 (Nikon). Quantification was performed using ImageJ software, at least four random fields of each section from each mouse liver were analyzed.

\section{Alcohol Clearance Analysis}

Mice were given a single dose of $31.5 \%$ (v/v) alcohol by gavage $(5 \mathrm{~g} / \mathrm{kg}$ of body weight). Blood was sampled from the tail vein before treatment and at 1,3 , and 9 hours after gavage. Alcohol concentration in the plasma was measured using an alcohol colorimetric/fluorometric assay kit (BioVision Inc., Milpitas, CA).

\section{Statistical Analysis}

Statistical analysis was performed using SPSS software version 17.0 (SPSS, Inc., Chicago, IL) or Excel 2016 (Microsoft Corp., Redmond, WA). The $t$-test was used to determine the significance of differences between two groups. The significance of differences between more than two treatment groups was determined using one-way analysis of variance followed by the Duncan post-hoc test. Data are expressed as means \pm SEM. Results were considered statistically significant at $P<0.05$.

\footnotetext{
Figure 1 Genetic deletion of autophagy genes exacerbates liver injury induced by acute alcohol binge. A: Scheme of acute binge treatment. Mice were treated with a single dose of alcohol (ethanol) or the same volume of distilled water $\left(\mathrm{ddH}_{2} 0\right)$ by gavage after 6 hours of fasting. Mice were euthanized 16 hours later. B and C: Liver weight and body weight (L/B) ratio, the serum levels of ALT, AST, ALP, and the hepatic levels of triglycerides (TG) and total cholesterol (TCH0) were measured in liver-specific Atg5-deficient mice 8 to 34 weeks old (B) and Atg7-deficient mice 8 to 16 weeks old (C). D: Scheme of the administration of alcohol to $A \operatorname{tg} 7^{\Delta \text { hep-ERT2 }}$ mice. Tamoxifen (TMX) was injected on days 1 and 2 to induce the deletion of Atg7. Alcohol or water was then given by oral gavage on day 8. $A \operatorname{tg} 7^{\mathrm{F} / \mathrm{F}}$ mice were used as control. E: L/B weight ratio, the serum levels of ALT, AST, ALP, and the hepatic levels of TG and TCHO were measured in induced $A t g 7^{\Delta \text { hep-ERT2 }}$ mice 8 to 15 weeks old. Data are expressed as means \pm SEM. $n=3$ to 5 (E); $n=3$ to 6 (C); $n=7$ to 14 (B). ${ }^{*} P<0.05$ versus nontreated $\mathrm{F} / \mathrm{F}$ control; ${ }^{\dagger} P<0.05$ versus nontreated $\Delta$ hep control; ${ }^{\ddagger} P<0.05$ versus treated $\mathrm{F} / \mathrm{F}$ control.
} 


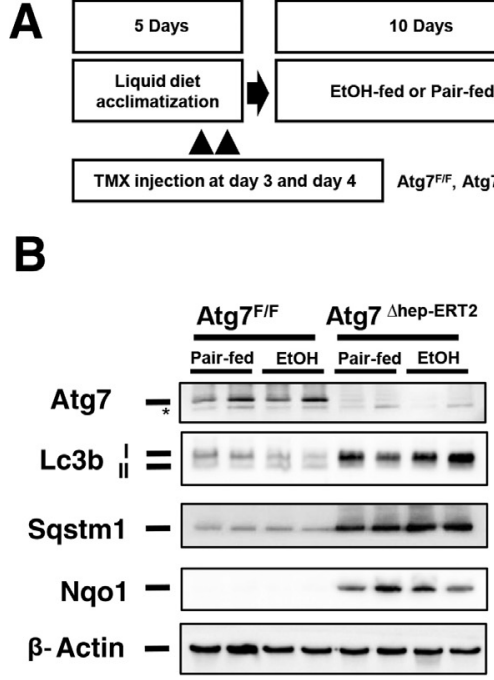

D
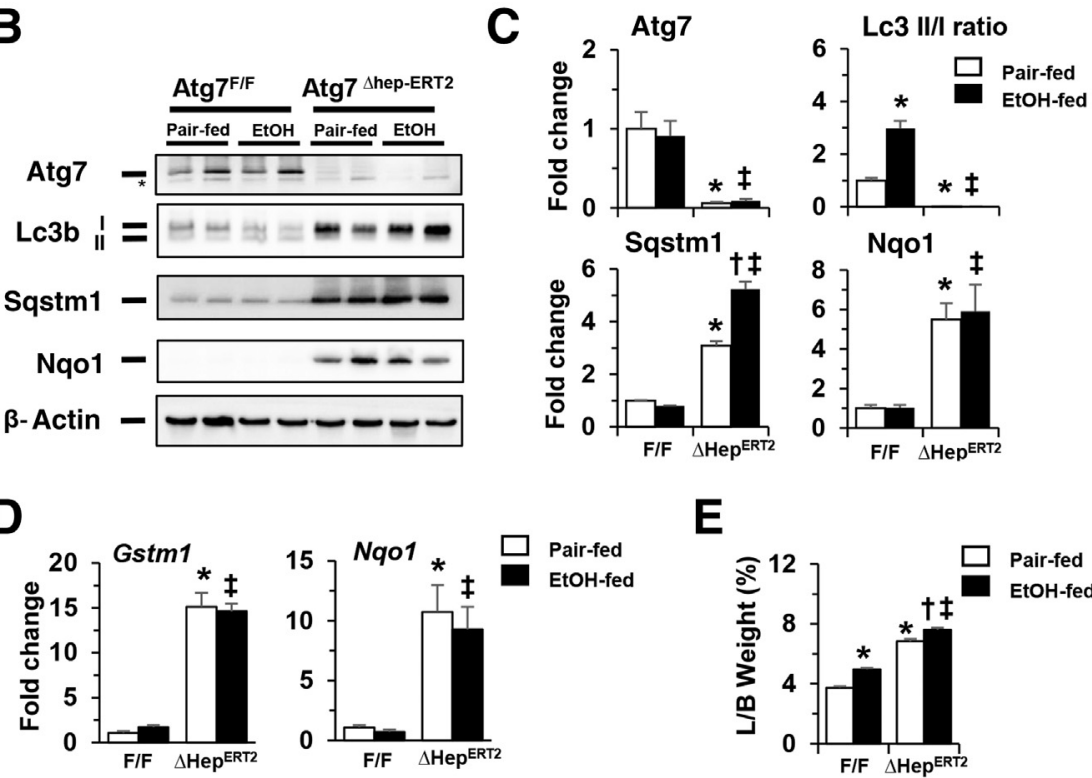

$E$

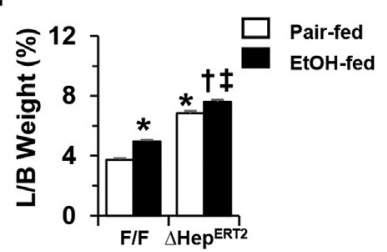

$\mathbf{F}$
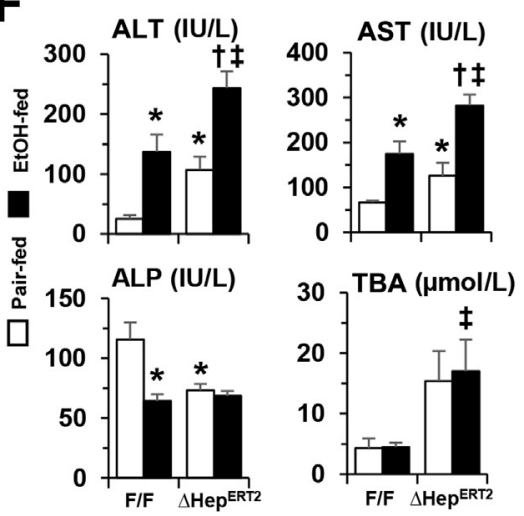

G

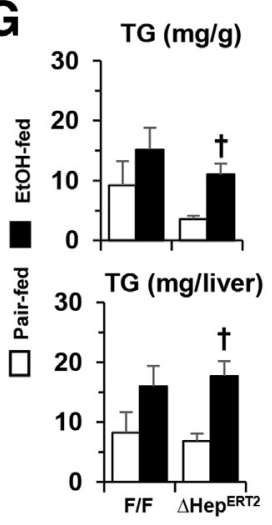

Figure 2 Acute deletion of Atg7 enhances alcohol-induced liver injury in a chronic-plus-binge model. A: Scheme of the chronic-plus-binge treatment. Mice were acclimated with liquid diet for 5 days. $A \operatorname{tg} 7^{\mathrm{F} / \mathrm{F}}$ and $A \operatorname{tg} 7^{\Delta \mathrm{hep}-\mathrm{ERT} 2}$ mice were injected with tamoxifen (TMX) on days 3 and 4 during acclimation. After acclimation, mice were randomly divided into two groups and given a liquid diet with alcohol (EtOH-fed) or with maltose dextrin (Pair-fed) for 10 days, followed by a single gavage of alcohol ( 5 $\mathrm{g} / \mathrm{kg}$ ) or isocaloric maltose dextrin. Mice were analyzed 9 hours later. B: Representative Western blot images of protein expression in the livers of $A \operatorname{tg} 7^{\mathrm{F} / \mathrm{F}}$ and $A \operatorname{tg} 7^{\mathrm{Ahep}-\mathrm{ERT} 2}$ mice after alcohol or pairfed treatment. Asterisk indicates onspecific bands. C: Densitometry of each protein band was conducted. The density values of $A \operatorname{tg} 7, \mathrm{p} 62$, or $\mathrm{Nad}(\mathrm{p}) \mathrm{h}$ quinone dehydrogenase (Nqo)-1 were normalized to that of $\beta$-actin. The density of microtubule-associated protein $1 \mathrm{~A} / 1 \mathrm{~B}$-light chain (LC)-3II was normalized to that of LC3I. D: The mRNA levels of Gstm1 and Nqo1 in the livers of $A t g 7^{\mathrm{F} / \mathrm{F}}$ and $A t g 7^{\Delta \text { hep-ERT2 }}$ mice after alcohol or pair-fed treatment. Expression levels were normalized to that of $\beta$-actin. $\mathbf{E}$ and $\mathbf{F}$ : Liver weight and body (L/B) weight ratio, serum levels of alanine aminotransferase (ALT), aspartate aminotransferase (AST), alkaline phosphatase (ALP), and total bile acids (TBA) in $A \operatorname{tg} 7^{\mathrm{F} / \mathrm{F}}$ and $A \operatorname{tg} 7^{\mathrm{Ahep} \text {-ERT2 }}$ mice after alcohol or pair-fed treatment. G: Hepatic triglycerides (TG) and serum $\beta$-hydroxybutyrate $(\beta$ OHB) levels in $A \operatorname{tg} 7^{\mathrm{F} / \mathrm{F}}$ and $A \operatorname{tg} 7^{\Delta \text { hep-ERT2 }}$ mice given alcohol or pair-fed treatment. Mice were used at the age of 8 to 12 weeks. Data are expressed as the means \pm SEM fold changes over those of pair-fed $A \operatorname{tg} 7^{\mathrm{F} / \mathrm{F}}$ mice. $n=4(\mathbf{A}, \mathbf{C}$, and $\mathbf{D}) ; n=4$ to $11(\mathbf{G}) .{ }^{*} P<0.05$ versus nontreated $\mathrm{F} / \mathrm{F}$ control; ${ }^{\dagger} P<0.05$ versus nontreated $\Delta$ hep control; ${ }^{\ddagger} P<0.05$ versus treated $\mathrm{F}$ / $\mathrm{F}$ control. Gstm1, glutathione S-transferase M1; and Nqo, $\operatorname{Nad}(p) h$ quinone dehydrogenase 1; Sqstm, sequestosome.

\section{Results}

\section{Effects of Genetic Deletion of a Key Autophagy Gene on Liver Injury Induced by Acute Alcohol Binge}

To evaluate the effects of hepatic autophagy deficiency on ALDs, one single binge-dose of alcohol was administered to the $\operatorname{Atg} 5^{\Delta \text { hep }}$ mice and the control mice (Figure 1A). Hepatic Atg5 deficiency was associated with significant hepatomegaly and liver injury (Figure 1B). Serum levels of ALT, AST, and ALP, and hepatic TG, but not hepatic TCHO, were further elevated in $\operatorname{Atg} 5^{\Delta \text { hep }}$ mice after alcohol treatment (Figure 1B), suggesting that acute alcohol treatment exacerbated the liver pathology in these mice. A protective function of autophagy against hepatic steatosis induced by acute alcohol administration has been shown in several studies. ${ }^{8,15,30,31}$

Genetic deletion of Atg7 in hepatic parenchymal cells caused a more severe liver phenotype than that seen in Atg $5^{\Delta \text { hep }}$ mice ${ }^{40}$ (Figure 1C). In these mice, a single binge dose of alcohol did not further lead to notable increases in serum levels of liver markers or hepatic TG level (Figure 1C). It seemed that a constitute deletion of Atg 7 in hepatic parenchymal cells caused too severe an injury so that the relative minor effects of acute alcohol treatment were blunted.

To separate the injury effect caused by constitutive $\operatorname{Atg} 7$ deletion and alcohol treatment, $\operatorname{Atg} 7^{\Delta \text { hep-ERT2 }}$ mice were injected with tamoxifen to induce an acute deletion of $A \operatorname{tg} 7$ in the liver before alcohol treatment (Figure 1D). The deficiency of hepatic autophagy in $\operatorname{Atg} 7^{\text {hep-ERT2 }}$ mice after 
A

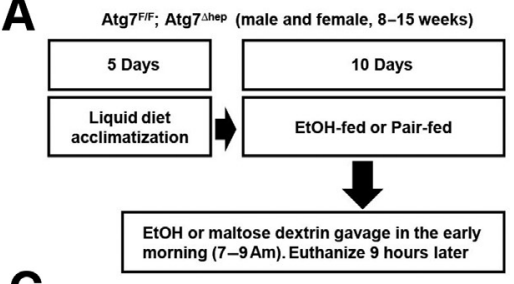

C

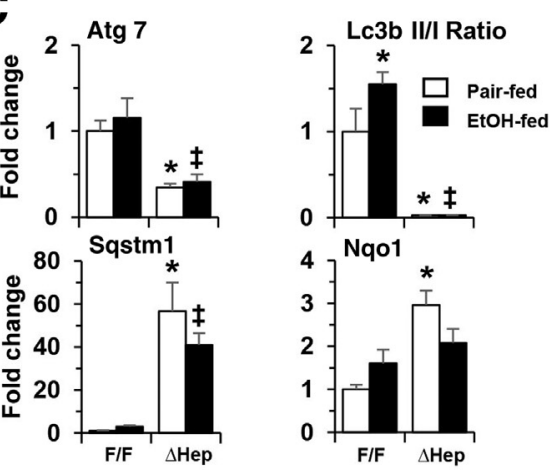

E

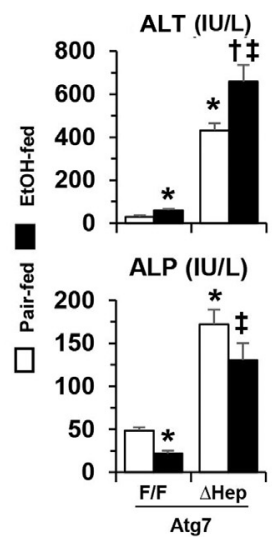

B

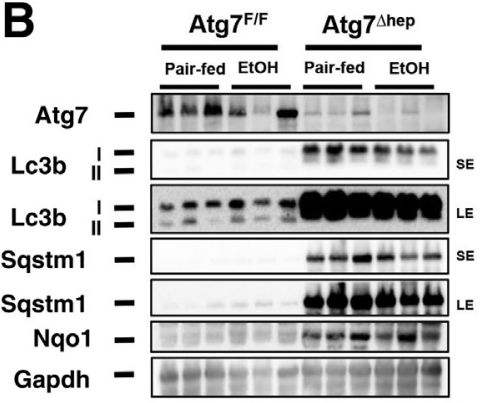

D

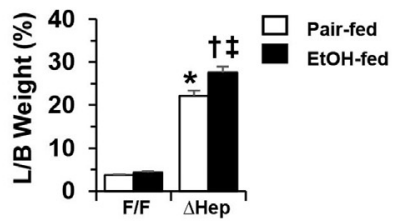

$\mathbf{F}$

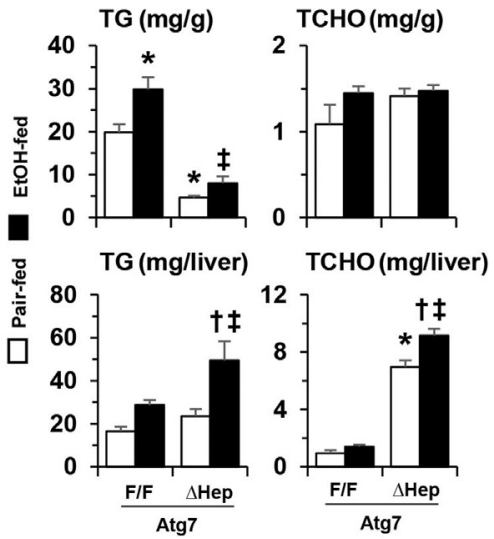

Figure 3 Constitutive deletion of hepatic Atg7 enhances alcohol-induced liver injury in a chronic-plus-binge model. A: Scheme of the chronic-plus-binge treatment. $A \operatorname{tg} 7^{\mathrm{F} / \mathrm{F}}$ and $A \operatorname{tg} 7^{\mathrm{Ahep}}$ mice were acclimated with liquid diet for 5 days. After acclimation, mice were randomly divided into two groups and given alcohol $(\mathrm{EtOH})$ or control diet as in Figure 2. B: Representative Western blot images of protein expression in the liver from $A \operatorname{tg} 7^{\mathrm{F} / \mathrm{F}}$ and $A \operatorname{tg} 7^{\Delta \text { hep }}$ mice after alcohol or pair-fed treatment. C: The density of Atg7, p62, or Nad(p)h quinone dehydrogenase (Nqo)-1 was normalized to that of glyceraldehyde phosphate dehydrogenase (Gapdh). The density of microtubule-associated protein 1A/1B-light chain (LC)-3II was normalized to that of LC3I. D and E: Liver weight and body (L/B) weight ratio, serum levels of alanine aminotransferase (Alt), aspartate aminotransferase (Ast), alkaline phosphatase (ALP), and total bile acids (TBA) in $A \operatorname{tg} 7^{\mathrm{F} / \mathrm{F}}$ and $A \operatorname{tg} 7^{\Delta \mathrm{hep}}$ mice after alcohol or pair-fed treatment. F: Hepatic triglycerides (TG) and total cholesterol (TCHO) levels in $A t g 7^{\mathrm{F} / \mathrm{F}}$ and $A \operatorname{tg} 7^{\mathrm{hhep}}$ mice given alcohol or pair-fed treatment. Mice were used at the age of 8 to 15 weeks. Data are expressed as the means \pm SEM fold changes over those of pairfed Atg $^{\mathrm{F} / \mathrm{F}}$ mice. $n=3$ (C), $n=3$ to 5 (F). ${ }^{*} P<0.05$ versus nontreated $\mathrm{F} / \mathrm{F}$ control; ${ }^{\dagger} P<0.05$ versus nontreated $\Delta$ hep control; ${ }^{\ddagger} P<0.05$ versus treated $\mathrm{F} / \mathrm{F}$ control. LE, long exposure; $\mathrm{SE}$, short exposure; Sqstm, sequestosome.

tamoxifen injection was confirmed by immunoblotting demonstration of decreases in hepatic microtubuleassociated protein $1 \mathrm{~A} / 1 \mathrm{~B}$-light chain (LC)-3II/LC3I ratio and the accumulation of sequestosome (SQSTM1)-1/p62 protein (Supplemental Figure S1). Obvious hepatomegaly and serum elevation in liver injury markers in the Atg $7^{\text {Dhep- }}$ ERT2 mice were not observed at 9 days after induction; however, the serum markers and hepatic TG levels were significantly increased after the acute alcohol treatment in these mice (Figure 1E). The results were consistent with previous results in which autophagy was modified transiently and acutely using chemicals or gene knockout. ${ }^{8,9,15}$ Therefore, an acute deletion of Atg7, while not causing liver injury alone, rendered the hepatocytes more susceptible to alcohol-induced injury.

\section{Effects of Acute Deletion of Atg7 Gene on Alcohol-Induced Liver Injury in a Chronic-Plus-Binge Model}

To further examine the impact of hepatic autophagy-deficiency alcohol exposure, the response of these genetically altered mice to a more chronic alcohol exposure was analyzed using a recently established chronicplus-binge model ${ }^{43}$ (Figure 2A). Atg $7^{\Delta \text { hep-ERT2 }}$ and $A \operatorname{tg} 7^{\mathrm{F} / \mathrm{F}}$ mice were given tamoxifen on days 3 and 4 in a 5-day 
A
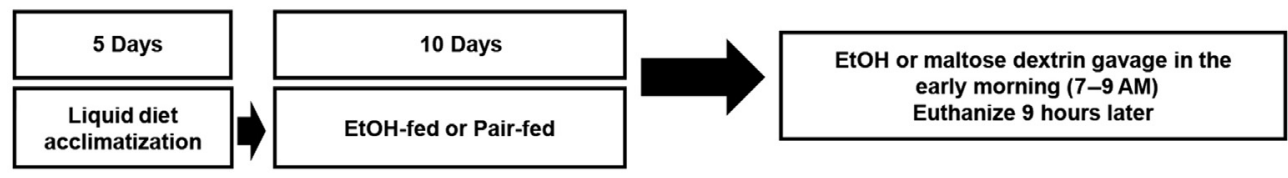

Atg5 ${ }^{\mathrm{F} / F} ; \operatorname{Atg}^{\mathrm{\Delta hep}}$ (male and female, 8-11 weeks and 18-24 weeks)

B

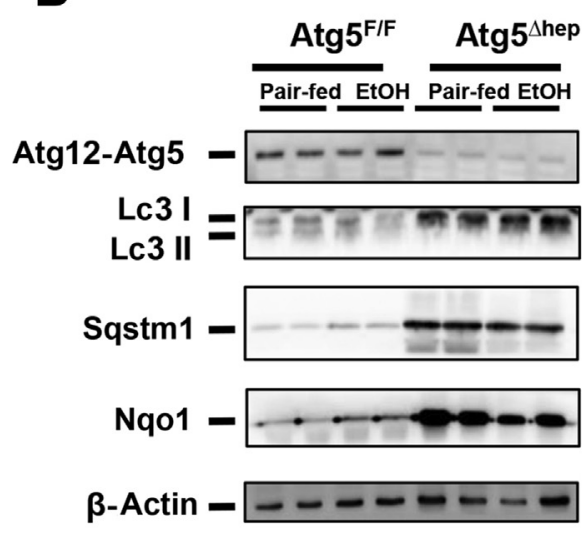

E

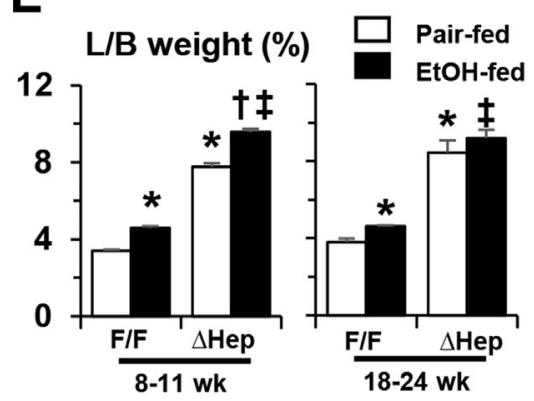

H

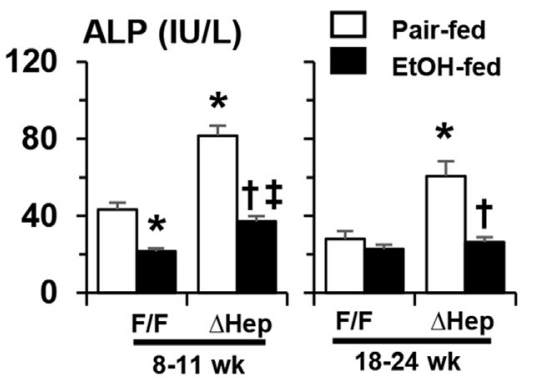

K

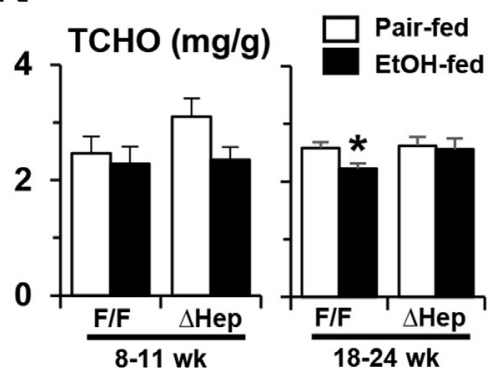

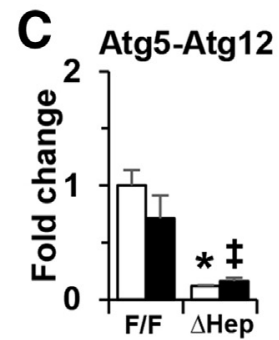
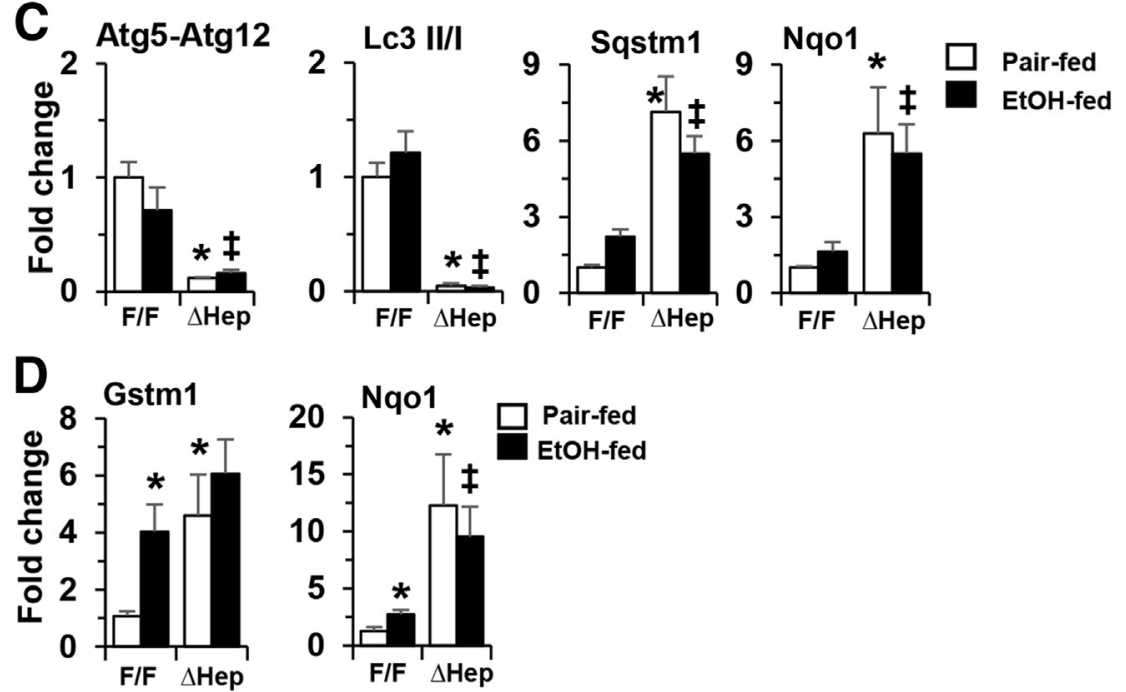

$\mathbf{F}$

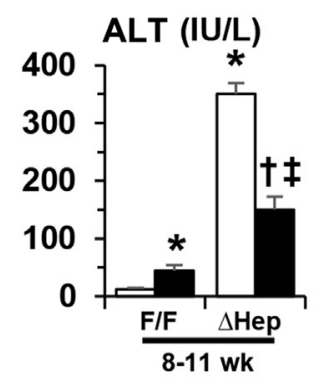

I

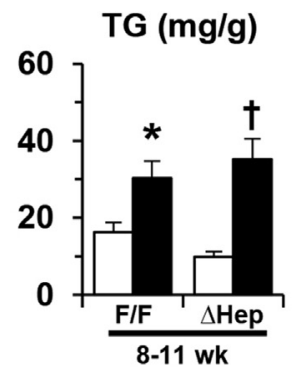

$\mathbf{L}$

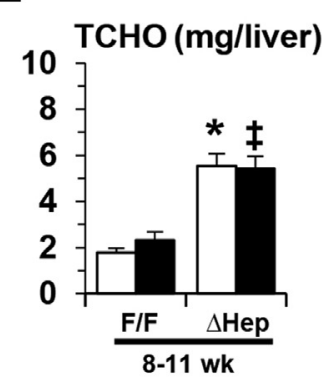

G
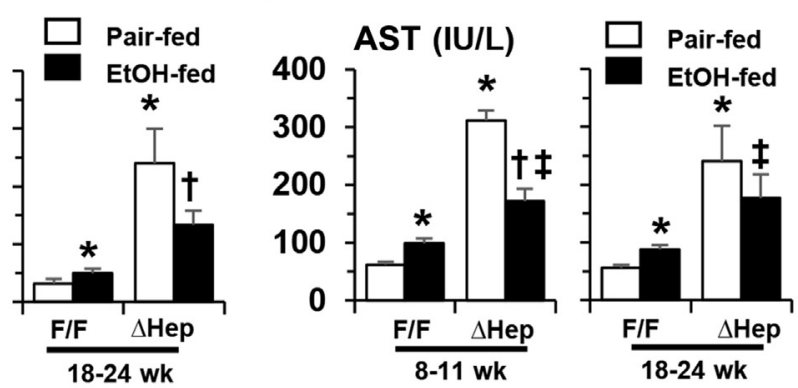

J
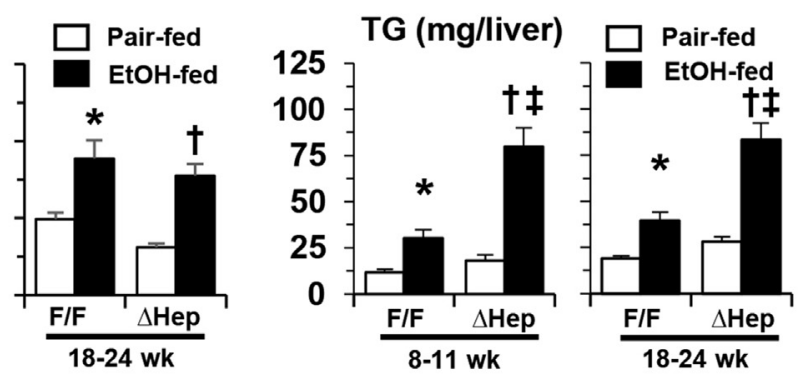
acclimation period, followed by an alcohol diet for 10 days plus an acute alcohol binge at the end of the feeding period. Autophagy deficiency was confirmed as indicated by reduced levels of $\operatorname{Atg} 7$ and LC3II/LC3I ratio, and elevated SQSTM1/ p62, in the livers of $A \operatorname{tg} 7^{\Delta \text { hep-ERT2 }}$ mice (Figure 2, B and C). Consistently, NF erythroid 2-related factor (Nrf)-2 was activated, and its targets, glutathione $S$-transferase M1 and $\mathrm{Nad}(\mathrm{p}) \mathrm{h}$ quinone dehydrogenase 1 , were expressed at much higher levels in the livers of $\operatorname{Atg} 7^{\Delta \text { hep-ERT2 }}$ mice (Figure 2, B-D). Notably, alcohol treatment did not alter these changes due to Atg7 deletion, although the LC3II/LC3I ratio was increased in the floxed normal mice (Figure 2, B-D).

A longer duration of $A \operatorname{tg} 7$ deletion in the $\operatorname{Atg} 7^{\Delta \text { hep-ERT2 }}$ mice resulted in enlarged livers and liver injury in the chronic-plus-binge model (Figure 2E) as compared with the shorter duration of deletion in the binge model (Figure 1E). But as in the binge model, hepatomegaly and liver injury phenotype (Alt and Ast levels), but not ALP or TBA, were further augmented by alcohol treatment (Figure 2F). These results suggest a protective function of Atg7-mediated autophagy in alcohol-induced liver injury.

To determine potential factors that promote injury in autophagy deficiency, the extent of steatosis was examined. Hepatic TG (Figure 2G), but not TCHO (Supplemental Figure S2A), level was altered after alcohol treatment, indicating the presence of steatosis in the livers of both $\operatorname{Atg} 7^{\mathrm{F} / \mathrm{F}}$ and $\operatorname{Atg} 7^{\mathrm{hhep}-\mathrm{ERT} 2}$ mice, but the difference was not significant between the two types of mice. Consistently, alcohol-induced elevation of fatty acid oxidation, as measured by the serum level of $\beta$-hydroxybutyrate, was not altered in the absence of $\operatorname{Atg} 7$ (Figure 2G).

Histologic examination suggested no obvious differences in general structure and fibrosis, but an elevated presence of Kupffer cells in autophagy-deficient livers (Supplemental Figure S2, B-E). Two acute-phase proteins, lipocalin-2 and serum amyloid A2, which are secreted by hepatocytes and other extrahepatic tissues in response to stress or injury, have been recently found to promote alcoholic liver pathology. ${ }^{44,45}$ Indeed, the expression levels of both lipocalin2 and serum amyloid A2 were elevated in $\operatorname{Atg} 7^{\Delta \text { hep-ERT2 }}$ livers, likely in response to autophagy deficiency-induced stress (Supplemental Figure S3A). After the 10-day chronic-plus-binge alcohol treatment, the expression levels of lipocalin-2 and serum amyloid A1 were elevated in floxed-control mice, but were not higher than the already elevated level in the Atg7-deficient livers (Supplemental Figure S3A). In addition, the mRNA levels of several inflammatory cytokines and inflammatory cell markers were higher in alcohol-treated $\operatorname{Atg} 7^{\Delta \text { hep-ERT2 }}$ livers than in the same treated floxed mice (Supplemental Figure S3, B and C). But the levels of several of these markers, such as C-C motif chemokine ligand 2 and Toll-like receptor 4 , were also elevated in $\operatorname{Atg} 7^{\Delta \text { hep-ERT2 }}$ livers without alcohol treatment. These findings suggest that the protective effect of autophagy may not be entirely related to modulation of inflammation.

\section{Effects of Constitutive Deletion of Hepatic Atg7 on Alcohol-Induced Liver Injury in a Chronic-Plus-Binge Model}

Chronic alcohol treatment caused more injury than did acute binge treatment (Figure 2E versus Figure 1E), which could allow the detection of Atg7-mediated protection even in the constitutive deletion model. Thus, in the $\operatorname{Atg} 7^{\Delta \text { hep }}$ and the control mice, alcohol diet was administered using the chronic-plus-binge scheme (Figure 3A). As in the inducible $\operatorname{Atg} 7^{\Delta \text { hep-ERT2 }}$ mice, the reduced $\operatorname{Atg} 7$ level and LC3II/LC3I ratio, and the accumulation of SQSTM1 and $\operatorname{Nad}(\mathrm{p}) \mathrm{h}$ quinone dehydrogenase 1 were not significantly altered in the livers of $\operatorname{Atg} 7^{\Delta \text { hep }}$ mice with an alcohol diet (Figure 3, B and C). Alcohol diet was associated with enhanced hepatomegaly (Figure 3D) and liver injury, based on increased serum levels of Alt and Ast (Figure 3E). There were no significant differences in the serum levels of ALP or TBA with or without alcohol treatment (Figure 3E). In addition, total hepatic TG and TCHO levels were increased in Atg7-deficient liver with alcohol treatment (Figure 3F). These results indicate that constitutive loss of $\operatorname{Atg} 7$ may exacerbate injury caused by chronic alcohol treatment as well.

\section{Effects of Constitutive Deletion of Hepatic Atg5 on Liver Injury in a Chronic-Plus-Binge Model}

A single dose of alcohol-binge treatment was associated with enhanced liver injury in $\operatorname{Atg} 5^{\Delta \text { hep }}$ mice (Figure 1B). Chronic alcohol treatment in $\operatorname{Atg} 5^{\Delta \text { hep }}$ mice (Figure 4A) was not associated with significant alterations in the repression of autophagy in these mice (Figure 4, B-D). Alcohol

\footnotetext{
Figure 4 Constitutive deletion of hepatic Atg5 does not enhance liver injury in a chronic-plus-binge model. A: Scheme of the chronic-plus-binge alcohol treatment. $A \operatorname{tg} 7^{\mathrm{F} / \mathrm{F}}$ and $A \operatorname{tg} 7^{\Delta \text { hep-ERT2 }}$ mice were injected with tamoxifen on days 3 and 4 during acclimation. After acclimation, mice were randomly divided into two groups and given a liquid diet with alcohol (EtOH-fed) or with maltose dextrin (Pair-fed) for 10 days, followed by a single gavage of alcohol ( $5 \mathrm{~g} / \mathrm{kg}$ ) or isocaloric maltose dextrin. Mice were analyzed 9 hours later. B: Representative Western blot images of protein expression in the liver from $A \operatorname{tg} 5^{\mathrm{F} / \mathrm{F}}$ and $A \operatorname{tg} 5^{\Delta \mathrm{Lhep}}$ mice after alcohol or pair-fed treatment. Anti-Agt12 antibody was used to detect the Atg12-Atg5 conjugate. C: The density of Atg5-Atg12, p62, or Nad(p)h quinone dehydrogenase (Nqo)-1 was normalized to that of $\beta$-actin. The density of microtubule-associated protein 1A/1B-light chain (LC)-3II was normalized to that of Lc3I. D: mRNA levels of Gstm1 and Nqo1 in livers of $A t g 5^{\mathrm{F} / \mathrm{F}}$ and $A \operatorname{tg} 5^{\Delta \text { hep }}$ mice after alcohol or pair-fed treatment. Expression levels were normalized to that of $\beta$-actin. E-H: Liver weight and body (L/B) weight ratio, serum levels of alanine aminotransferase (ALT), aspartate aminotransferase (AST), and alkaline phosphatase (ALP) in $A \operatorname{tg} 5^{\mathrm{F} / \mathrm{F}}$ and $A \operatorname{tg} 5^{5^{\text {hep }}}$ mice after alcohol or pair-fed treatment. I-L: Hepatic triglycerides (TG) and total cholesterol (TCHO) levels in $A \operatorname{tg} 5^{\mathrm{F} / \mathrm{F}}$ and $A \operatorname{tg} 5^{\Delta \text { hep }}$ mice given alcohol or pair-fed treatment. Data are expressed as the means $\pm \mathrm{SEM}$ fold changes over pair-fed $A \operatorname{tg} 5^{\mathrm{F} / \mathrm{F}}$ mice. $n=4(\mathrm{C})$; $n=6$ (D); $\mathrm{n}=7$ to $18(\mathbf{E}-\mathbf{H}) .{ }^{*} P<0.05$ versus nontreated $\mathrm{F} / \mathrm{F}$ control; ${ }^{\dagger} P<0.05$ versus nontreated $\Delta$ hep control; ${ }^{\ddagger} P<0.05$ versus treated $\mathrm{F} / \mathrm{F}$ control.
} 
A

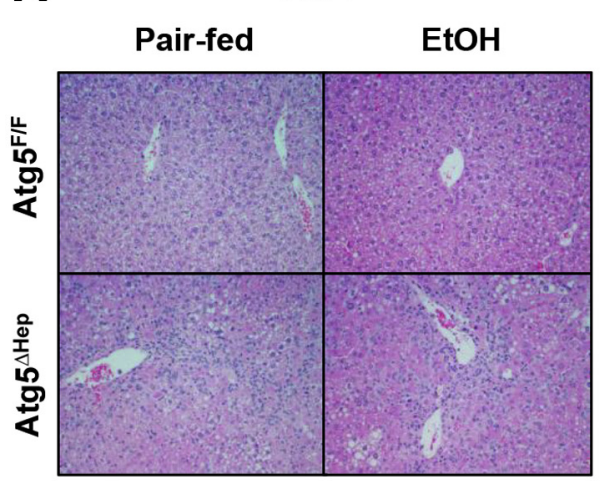

D

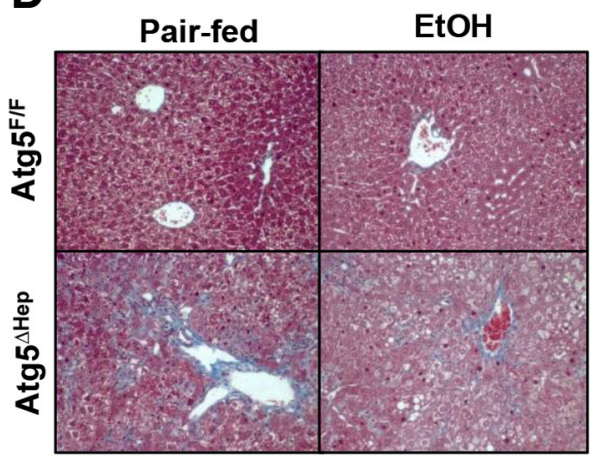

B

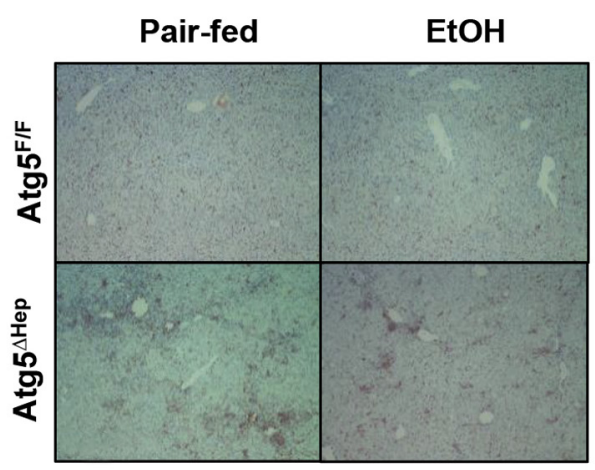

E

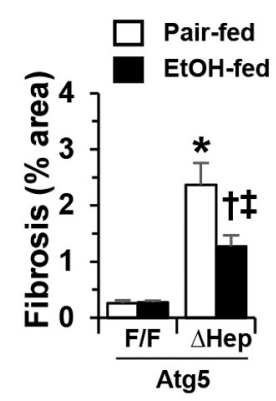

$F 4 / 80$

C

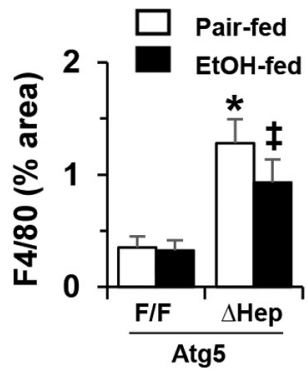

G

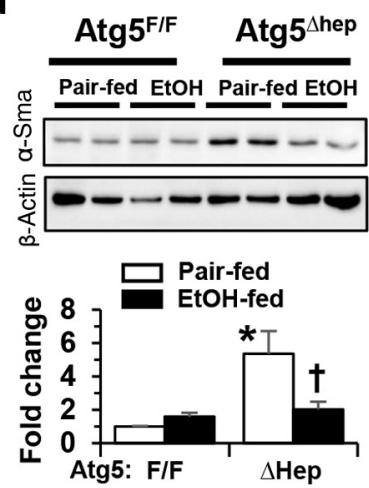

H

Pair-fed EtOH-fed
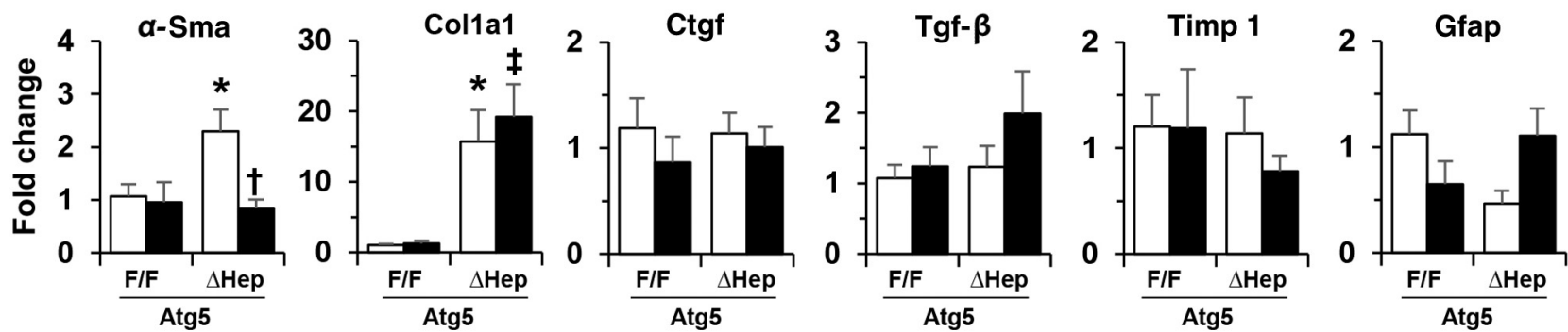

Figure 5 Reduced inflammation and fibrosis in constitutive Atg5-deficient livers after chronic-plus-binge alcohol treatment. A-E: $A \operatorname{tg} 7^{\mathrm{F} / \mathrm{F}}$ and $\operatorname{Atg}^{\mathrm{Ahep}-}$ ERT2 mice (18 to 24 weeks old) were injected with tamoxifen on days 3 and 4 during acclimation. After acclimation, mice were randomly divided into two groups and given a liquid diet with alcohol (EtOH-fed) or with maltose dextrin (Pair-fed) for 10 days, followed by a single gavage of alcohol ( $5 \mathrm{~g} / \mathrm{kg}$ ) or isocaloric maltose dextrin. Mice were analyzed 9 hours later. Liver sections were subjected to hematoxylin and eosin (H\&E) staining (A), F4/80 stain and quantified (B and $\mathbf{C}$ ), and Masson's trichrome stain and quantified (D and E). F: The hepatic hydroxyproline level was determined. G: Representative Western blot images of $\alpha$-smooth muscle actin (Sma) protein and densitometric analysis. The density of $\alpha$-Sma protein was normalized to that of $\beta$-actin. H: The mRNA expression of fibrosis-related genes in the livers of $A \operatorname{tg} 5^{\mathrm{F} / \mathrm{F}}$ and $A \operatorname{tg} 5^{\mathrm{shep}}$ mice given alcohol or control diet. Expression levels of indicated genes were determined by real-time quantitative -PCR and were normalized to that of $\beta$-actin. Data are expressed as the means \pm SEM fold-changes over those of $A$ tg $5^{F / F}$ mice given the pair-fed diet. $n=4(\mathbf{G}) ; n=5$ to $6(\mathbf{F}) ; n=6(\mathbf{H}) .{ }^{*} P<0.05$ versus nontreated $\mathrm{F} / \mathrm{F}$ control; ${ }^{\dagger} P<0.05$ versus nontreated $\Delta$ hep control; ${ }^{\ddagger} P<0.05$ versus treated F/F control. Original magnification, $\times 200$ (A, B, and D). Ctgf, connective tissue growth factor; Gfap, glial fibrillary acidic protein; Tgf, transforming growth factor; Timp1, tissue inhibitor of metallopeptidase 1.

treatment was associated with slightly increased hepatomegaly in younger $\operatorname{Atg} 5^{\text {hep }}$ mice (Figure 4E), and with significant decreases in the serum levels of Alt, Ast, and ALP in both younger and older $\operatorname{Atg} 5^{\text {hep }}$ mice (Figure 4, $\mathrm{F}-\mathrm{H})$. The reduced injury was observed in both male and female mice (Supplemental Figures S4A and S5A). Total hepatic TG level but not TCHO level was still increased in
$\operatorname{Atg} 5^{\Delta \text { hep }}$ and in $\operatorname{Atg} 5^{\mathrm{F} / \mathrm{F}}$ mice after alcohol treatment (Figure 4, I-L, and Supplemental Figures S4B and S5B), indicating an expected hepatic response to alcohol. Consistent with a higher level of total hepatic TG in $\operatorname{Atg} 5^{\Delta \text { hep }}$ mice after alcohol treatment, hematoxylin and eosin staining of the liver sections also showed a more prominent hepatic steatosis in these mice (Figure 5A). 
A
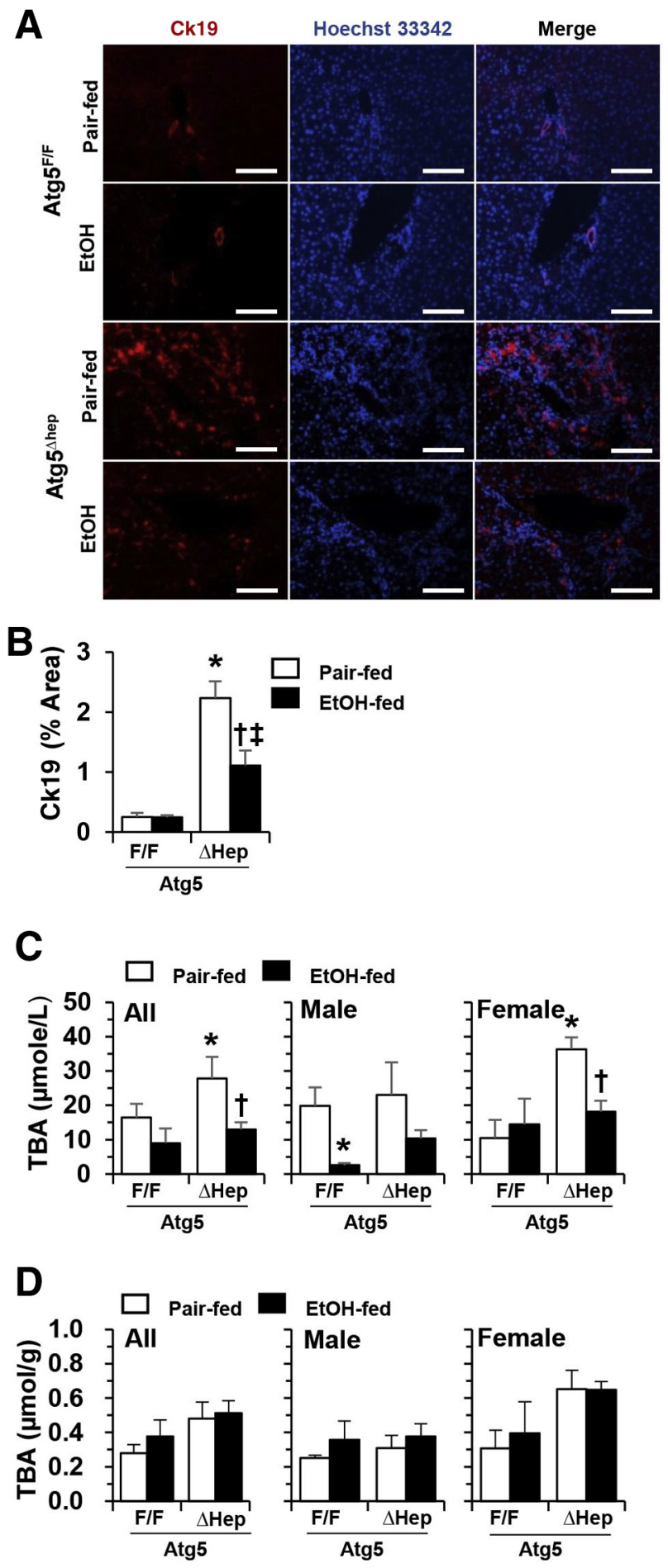

E

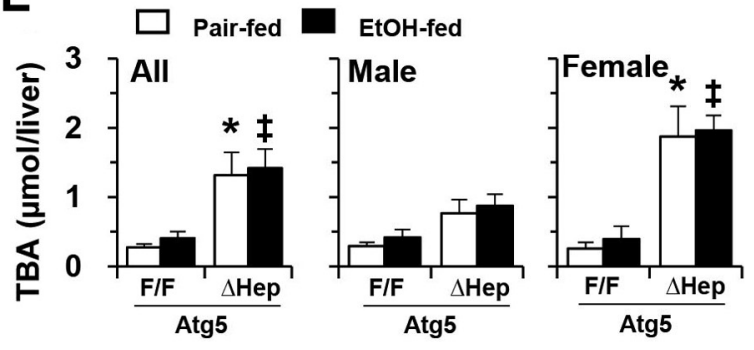

It is well established that elevation of hepatic TG level is an immediate consequence of alcohol stimulation, and that steatosis is also a major pathologic phenomenon in AFLD. ${ }^{46,47}$ Generally, alcohol can affect hepatic lipid metabolism by accelerating lipogenesis, decelerating lipid breakdown, and causing defective hepatic lipid export. ${ }^{47}$ The mRNA expression levels of several lipid metabolism related-genes in the $\operatorname{Atg} 5^{\Delta \text { hep }}$ mice were altered from those in the $\operatorname{Atg} 5^{\mathrm{F} / \mathrm{F}}$ mice before and/or after alcohol treatment (Supplemental Figure S6, A-E). The expression levels of genes involved in lipid secretion, such as apolipoprotein B (Apob) and Apoe, were reduced, whereas the expression levels of genes involved in lipid update, such as cluster of differentiation $36(C d 36)$ and lipoprotein lipase $(L p l)$, were increased before or after alcohol treatment. Although the expression levels of the genes involved in lipogenesis, except stearoyl-Coenzyme (Co)-A desaturase 1 ( $S c d 1)$, were not elevated, the expression levels of the genes involved in lipolysis, such as adipose triglyceride lipase $(A t g l)$ and hormone-sensitive lipase E (Lipe), and the genes in lipid oxidation, such as acyl-CoA dehydrogenase, long-chain (Acadl), acyl-CoA dehydrogenase medium chain (Acadm), peroxisomal acyl-CoA oxidase 1 (Acoxl), and peroxisome proliferator-activated receptor $\alpha$ (Ppara), were repressed. Moreover, the expression levels of the genes involved in lipid oxidation were overall reduced in $\operatorname{Atg} 5^{\Delta \text { hep }}$ mice (Supplemental Figure S6E); however, the serum level of $\beta$ hydroxybutyrate remained elevated in response to alcohol stimulation (Supplemental Figure S6F). These changes may overall favor the accumulation of lipids in the cells and decrease lipid use.

The number of $\mathrm{F} 4 / 80^{+}$-staining macrophages was significantly increased in $\operatorname{Atg} 5^{\Delta \text { hep }}$ livers, similar to what was observed in $A \operatorname{tg} 7^{\Delta \text { hep }}$ livers. ${ }^{48}$ The level of macrophage expansion was noticeably reduced with alcohol treatment (Figure 5, B and C). The expression levels of many inflammation-related genes were not significantly altered in Atg5-deficient livers, except C-C motif chemokine ligand 2, which was increased in Atg5-deficient livers (Supplemental Figure S7). Alcohol treatment was associated with reduce levels of C-C motif chemokine ligand 2 and several other cytokines and inflammatory cell markers in these mice

Figure 6 Reduced cholestasis in constitutive Atg5-deficient livers afte chronic-plus-binge alcohol treatment. $\operatorname{Atg} 7^{\mathrm{F} / \mathrm{F}}$ and $\operatorname{Atg} 7^{\Delta \text { hep-ERT2 }}$ mice (18 to 24 weeks old) were injected with tamoxifen on days 3 and 4 during acclimation. After acclimation, mice were randomly divided into two groups and given a liquid diet with alcohol (EtOH-fed) or with maltose dextrin (Pair-fed) for 10 days, followed by a single gavage of alcohol $(5 \mathrm{~g} / \mathrm{kg})$ or isocaloric maltose dextrin. Mice were analyzed 9 hours later. A: Liver sections were immunostained with anti-cytokeratin (Ck)-19. B: Ck19-positive areas were quantified. C: Serum levels of total bile acids (TBA). D and E: The levels of TBA in each gram of liver (D) or in the whole liver (E) were determined. Data are expressed as means \pm SEM. $n=3(\mathbf{D}$ and $\mathbf{E}) ; n=4$ to 5 (B); $n=4$ to 7 (A, female); $n=6$ to 12 (A, male). ${ }^{\star} P<0.05$ versus nontreated $\mathrm{F} / \mathrm{F}$ control; ${ }^{\dagger} P<0.05$ versus nontreated $\Delta$ hep control; ${ }^{\ddagger} P<0.05$ versus treated $\mathrm{F} / \mathrm{F}$ control. Scale bar $=0.1 \mathrm{~mm}$. 
A

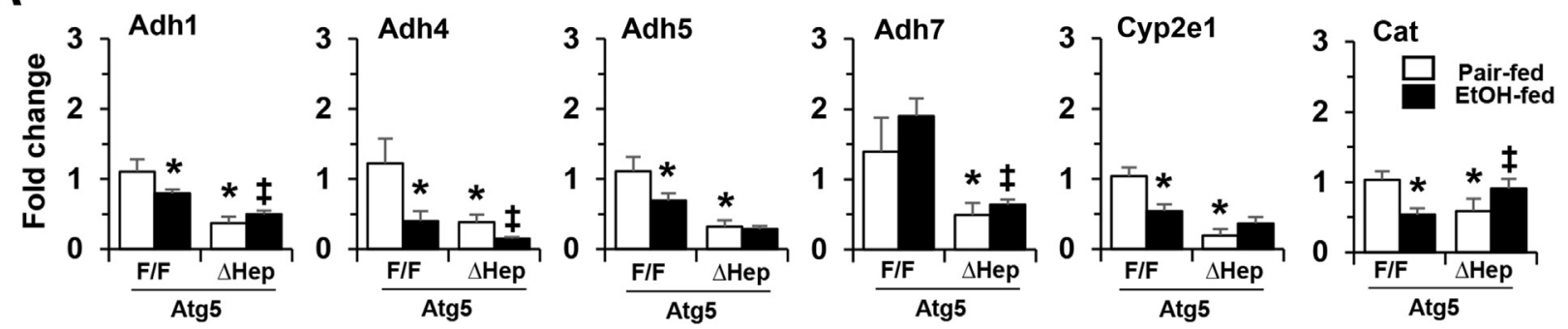

B
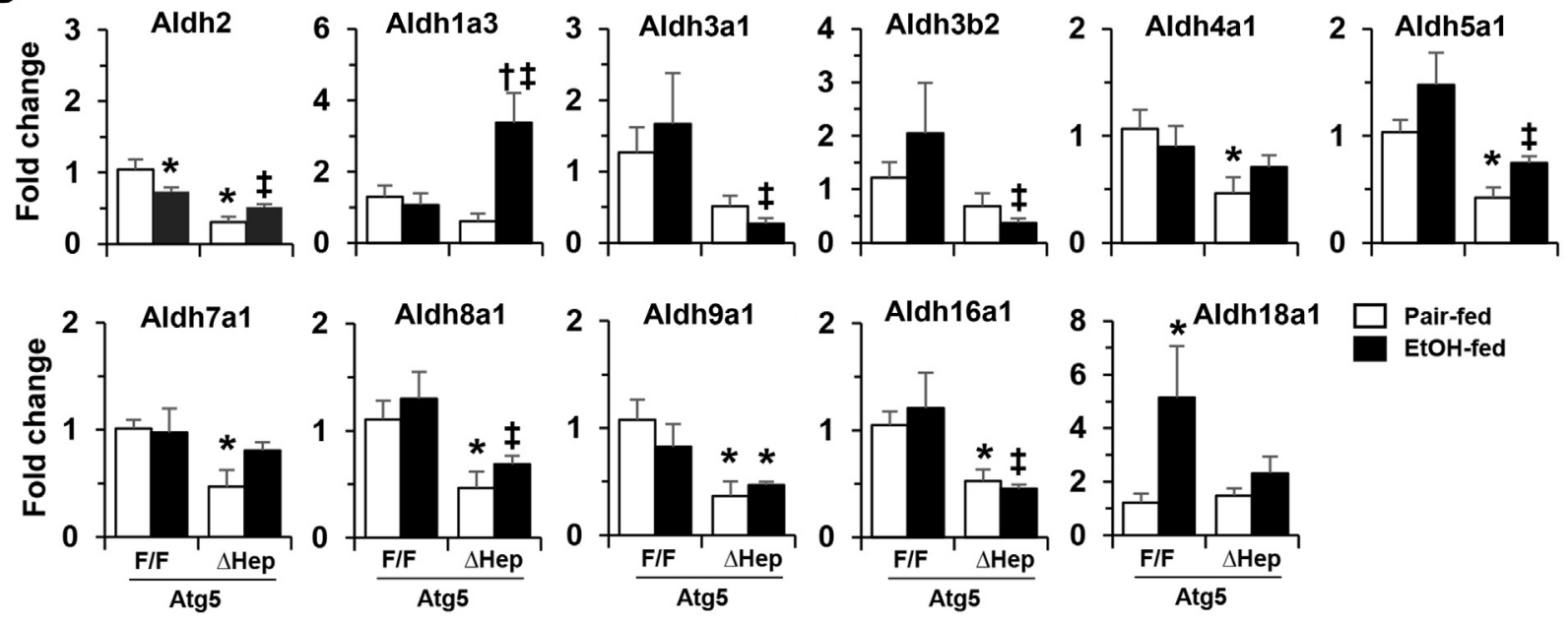

Pair-fed EtOH-fed
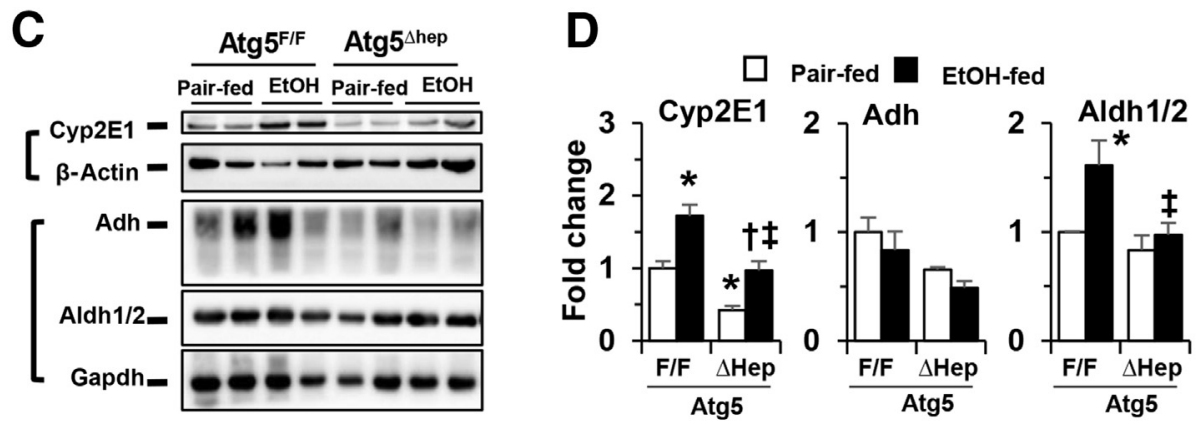

E

Figure 7 Constitutive deletion of hepatic Atg5 alters the expression of genes related to alcohol metabolism and serum alcohol clearance. Atg $7^{\mathrm{F} / \mathrm{F}}$ and Atg $7^{\Delta \text { hep-ERT2 }}$ mice (18 to 24 weeks old) were injected with tamoxifen on days 3 and 4 during acclimation. After acclimation, mice were randomly divided into two groups and given a liquid diet with alcohol (EtOH-fed) or with maltose dextrin (Pair-fed) for 10 days, followed by a single gavage of alcohol ( $5 \mathrm{~g} / \mathrm{kg}$ ) or isocaloric maltose dextrin. Mice were analyzed 9 hours later. A and B: The mRNA levels of genes related to the oxidation of alcohol (A) or acetaldehyde (B) in the liver. C: The protein levels of key alcohol-metabolizing enzymes in the liver. $\beta$-Actin [for cytochrome P450 (Cyp)-2e1] and glyceraldehyde phosphate dehydrogenase (Gapdh) [for aldehyde dehydrogenase (Aldh)-1/2 and alcohol dehydrogenase (Adh)] were used as loading control. D: Densitometry was conducted, and the density levels were normalized to that of loading control. E: $\operatorname{Atg} 5^{\mathrm{F} / \mathrm{F}}$ and $A \operatorname{tg} 5^{\mathrm{Shep}}$ mice at the age of 13 to 20 weeks were given a single dose of alcohol binge $(5 \mathrm{~g} / \mathrm{kg})$. Plasma alcohol concentrations were then measured at 1,3 , and 9 hours later. Data are expressed as the means $\pm \mathrm{SEM}$ fold changes over $A \operatorname{tg} 5^{\mathrm{F} / \mathrm{F}}$ mice given pair-fed treatment. $n=3$ to $5(\mathbf{E}) ; n=4(\mathbf{D}) ; n=6(\mathbf{A}$ and $\mathbf{B}) .{ }^{*} P<0.05$ versus nontreated $\mathrm{F} / \mathrm{F}$ control; ${ }^{\dagger} P<0.05$ versus nontreated $\Delta$ hep control; ${ }^{\ddagger} P<0.05$ versus treated F/F control; ${ }^{\circledR \S \S} P<0.001$. Atg, autophagy-related protein; Cat, catalase.

(Supplemental Figure S7, A and B). On the other hand, the expression levels of lipocalin-2 and serum amyloid A2 remained higher (Supplemental Figure S7C). Inflammation plays important roles in the pathogenesis of ALFD. ${ }^{49}$ In particular, $\mathrm{C}-\mathrm{C}$ motif chemokine ligand 2 is associated with the severity of, and neutrophil infiltrates in, ALD. ${ }^{50}$ Thus, the reduction of inflammation in chronic alcohol treatment condition may contribute to the reduced injury level in Atg $5^{\Delta \text { hep }}$ livers.
Interestingly, the significantly elevated fibrosis in Atg5deficient livers was also decreased by chronic alcohol treatment, as shown by Masson's trichrome staining (Figure 5, D and E), hydroxyproline level (Figure 5F), and the expression of $\alpha$-smooth muscle actin, at the protein (Figure 5G) and the mRNA levels (Figure 5H). The levels of other fibrosis-related genes, such as connective tissue growth factor (Ctgf), transforming growth factor $\beta 1(T g f b 1)$, tissue inhibitor of metallopeptidase 1 (Timpl), and glial 
fibrillary acidic protein (Gfap), were not significantly different between alcohol treatment and control diet (Figure 5H). This improving effect of alcohol is reminiscent of findings from an earlier study showing a potentially protective effect of light alcohol consumption on hepatocellular injury and liver fibrosis in patients with NAFLD. ${ }^{51}$ It seems that alcohol may have variable effects on hepatic fibrosis in different pathologic conditions, which may partially explain the improvement in liver fibrosis in Atg5deficient livers after alcohol treatment.

\section{Reduction in Cholestatic Injury in Atg5-Deficient Livers after Alcohol Treatment}

Autophagy deficiency in the liver can cause cholestatic injury, which is accompanied by a significant ductular reaction. ${ }^{48,52}$ Alcohol treatment was associated with a reduction in this pathologic change in $\operatorname{Atg} 5^{\Delta \text { hep }}$ livers, as measured by the level of cytokeratin-19-positive ductular cell (Figure 6, A and B). Consistently, the serum level of TBA was also decreased after alcohol treatment in $\operatorname{Atg} 5^{\Delta \text { hep }}$ mice if both sexes and at both the older (Figure 6C) and younger (Supplemental Figure S8A) ages. Similar chronic alcohol treatment in $\operatorname{Atg} 7^{\text {hhep-ERT2 }}$ (Figure 2F) or $\operatorname{Atg} 7^{\text {Dhep }}$ (Figure 3E) mice was not associated with reductions in the elevated serum TBA levels in these mice. Unexpectedly, the hepatic TBA load remained high in $\operatorname{Atg} 5^{\Delta \text { hep }}$ mice even after alcohol treatment, regardless of age (Figure 6, D and E, and Supplemental Figure S8, B and C). Interestingly, $\operatorname{Atg} 5^{\Delta \text { hep }}$ mice given one dose of alcohol binge also showed a reduced serum bile acid level, in contrast to $\operatorname{Atg} 7^{\text {hep }}$ and $\operatorname{Atg} 7^{\Delta \text { hep- }}$ ERT2 mice given the same acute treatment (Supplemental Figure S8D).

The mRNA levels of genes related to bile acid metabolism were analyzed to determine any potential effects of alcohol. The expression levels of many of these genes were decreased in Atg5-deficient livers, as previously reported ${ }^{52}$ (Supplemental Figure S9). However, overall, the mRNA levels of genes related to bile acid synthesis were not further significantly altered in Atg5-deficient liver after alcohol treatment (Supplemental Figure S9, A and B). In addition, the expression of genes related to farnesoid $\mathrm{X}$ receptor (FXR) signaling remained low in Atg5-deficient livers (Supplemental Figure S9C). The impact of autophagy deficiency on the expression of the bile acid transporters, most of which were not further significantly affected by the alcohol (Supplemental Figure S9, D-F), has been reported before. ${ }^{52}$ Exceptions were the expression levels of organic solute transporter $\beta$ in $\operatorname{Atg} 5^{\Delta \text { hep }}$ liver (Supplemental Figure S9E) and organic anion transporting polypeptide 1 (OATP1) in $\operatorname{Atg} 5^{\mathrm{F} / \mathrm{F}}$ liver (Supplemental Figure S9F), which were significantly decreased after alcohol treatment. Geneexpression results indicated that the influence of alcohol on bile acid metabolism in Atg5-deficient livers would likely be limited.
Hepatic Atg5 Deficiency and the Expression of Genes Related to Alcohol Metabolism and the Plasma Alcohol Clearance Rate in Mice

Acetaldehyde along with other alcohol metabolites are considered to be involved in ALDs. ${ }^{53}$ Since alcohol-induced liver injury is affected by alcohol metabolism, it was tested whether alcohol metabolism was affected in Atg5-deficient livers. The expression levels of genes related to alcohol metabolism were analyzed. Notably, the mRNA levels of several alcohol dehydrogenase (Adh)-related genes, including Adh classes I to IV (Adhl, -4, -5, and -7, respectively), were decreased in Atg5-deficient livers (Figure 7A). The expression levels of cytochrome P450 (Cyp) family 2 subfamily $\mathrm{E}$ member 1 and catalase were also decreased in Atg5-deficient livers (Figure 7A). Interestingly, the mRNA levels of Adhl, Adh4, Adh5, Cyp2el, and Cat were also decreased in the livers of $A \operatorname{tg} 5^{\mathrm{F} / \mathrm{F}}$ mice after alcohol treatment.

The mRNA levels of several aldehyde dehydrogenases (Aldh) in the liver were analyzed. Significant decreases in the mRNA expression levels of Aldh2, -4al, -5al, -7al, $-8 a 1$, and $-9 a 1$ were observed in the Atg5-deficient livers (Figure 7B). Although alcohol did not seem to cause further changes in the expression levels of most of these genes, it was associated with elevated Aldhla3 gene expression in Atg5-deficient livers, and elevated Aldh18al gene expression in $A \operatorname{tg} 5^{\mathrm{F} / \mathrm{F}}$ livers (Figure 7B). The expression levels of several other Aldh family members, including Aldhlal, $-1 a 2,-1 b 1,-111,-112,-3 a 2,-3 b 1$, and $-6 a 1$, were not significantly changed in the livers of Atg5-deficient mice or with alcohol treatment (Supplemental Figure S10).

The protein levels of Adh, Cyp2e1, and Aldh1/2 were further analyzed. Protein stability of CYP2E1 is crucial to its induction by alcohol. ${ }^{54}$ The protein levels of Cyp2e1 and Adh were decreased in older (18 to 24 weeks) (Figure 7, C and D) and younger (8 to 11 weeks) (Supplemental Figure S11) Atg5-deficient livers. However, consistent with findings from a previous study, ${ }^{54}$ the protein level of Cyp2e1 was significantly increased after alcohol treatment in the livers of both $\operatorname{Atg} 5^{\Delta \text { hep }}$ and $\operatorname{Atg} 5^{\mathrm{F} / \mathrm{F}}$ mice (Figure 7, C and D, and Supplemental Figure S9). No consistent changes in Adh or Aldh1/2 in either older (18 to 24 weeks) or younger ( 8 to 1 week) mice were observed (Figure 7, C and D, and Supplemental Figure S9). The gene-expression and protein-expression data indicate that Atg5 deficiency in the liver alters the expression of genes related to alcohol metabolism; however, alcohol itself did not seem to have affected the mRNA levels of most of these genes. These changes could result in a lower metabolism of alcohol and therefore lower levels of metabolites of alcohol that are known to be involved in its toxicity.

The lower metabolism of alcohol might cause a higher plasma alcohol level in the Atg5-deficient mice. To examine this possibility, $\operatorname{Atg} 5^{\Delta \text { hep }}$ and $\operatorname{Atg} 5^{\mathrm{F} / \mathrm{F}}$ mice were given a single dose of alcohol by gavage, and the plasma levels of alcohol were 
measured at different time points (Figure 7E). The plasma alcohol in nontreated mice was undetectable. The plasma levels of alcohol at 1 hour after gavage were comparable between $\operatorname{Atg} 5^{\mathrm{Shep}}$ and $\operatorname{Atg} 5^{\mathrm{F} / \mathrm{F}}$ mice, suggesting that there was no difference in the intestinal absorption of alcohol (Figure 7E). Interestingly, plasma levels of alcohol were slightly lower at 3 hours and dramatically lower at 9 hours in $\operatorname{Atg} 5^{\text {hhep }}$ mice than those in $\operatorname{Atg} 5^{\mathrm{F} / \mathrm{F}}$ mice (Figure 7E). These results indicate an increased plasma alcohol clearance in $\operatorname{Atg} 5^{\Delta \text { hep }}$ mice despite reductions in the expression of genes in the alcohol-metabolism pathway. Other mechanisms may therefore account for the alcohol elimination in the autophagy-deficient mice.

\section{Discussion}

\section{Effects of How Autophagy Is Inhibited and How Alcohol Is Administered on Alcohol-Induced Liver Injury}

This is the first study in which the role of autophagy in alcohol-induced liver injury was assessed through a genetic approach to disrupt the formation of autophagosomes using either inducible or constitutive knockout of two different autophagy genes, Atg 7 and Atg5. These models differ in the duration of autophagy deficiency, the specific gene being affected, and the severity of endogenous liver injury. This study thus allows an extensive analysis of the interaction of alcohol administration and autophagy function in the context of acute and chronic liver injury.

Previous studies have examined the role of autophagy by using siRNA-mediated knockdown of Atg7, or by interference of the lysosomal functions with chloroquine or transcription factor EB. ${ }^{8,9,12,15,31}$ In these studies, the protective role of autophagy in alcohol-induced liver injury had been shown in the models of an acute binge, a chronic 4-week Liber-DeCarli feeding, and a chronic-plus-binge feeding. The protective effects of autophagy in the gastric-infusion model had also been observed with the use of chloroquine (J.Z. and X.-M.Y., unpublished data). In the infusion model, alcohol (up to $37.1 \%$ of calorie uptake) was given in either an $8 \%$ low-fat or $40 \%$ high-fat base over a period of 28 days. ${ }^{55}$ The administration of chloroquine led to increased hepatic TG and blood ALT.

Here we have confirmed the protective effect of autophagy in the inducible $\operatorname{Atg} 7$-deficient livers (Atg $7^{\Delta \text { hep-ERT2 }}$ ) using both the acute binge model and a new chronic-plus-binge model. In both models, autophagy deficiency via Atg7 deletion was induced only shortly before alcohol treatment. The inducible approach minimized the liver injury caused by autophagy deficiency alone, so that the impact of autophagy deficiency on alcohol-induced injury could be directly examined. However, mice harboring constitutive deletion of Atg7 $\left(\operatorname{Atg} 7^{\text {hhep }}\right.$ ) had different responses to alcohol treatment in the acute binge and chronic-plus-binge models. Liver injury was noticeably enhanced in $\operatorname{Atg} 7^{\text {hhep }}$ mice after the chronic-plusbinge treatment, but not after acute binge treatment. The difference in the liver injury after alcohol treatments between the two Atg7-deletion models may have been due to the difference in the durations of gene deletion, which would have resulted in varying levels of autophagy dysfunction and liver injury. It is possible that a higher level of detrimental SQSTM1/ p62 accumulation and NRF2 activation in the $\operatorname{Atg} 7^{\Delta \text { hep }}$ mice (Figure 3, B and C, and Figure 2, B and C) may have accounted for this resistance.

In mice with constitutive Atg5 deletion in the liver $\left(\right.$ Atg $\left.5^{\Delta \text { hep }}\right)$, liver injury was noticeably enhanced after a single dose of binge treatment, but paradoxically improved after the chronic-plus-binge treatment. In the latter, the improved presentation included lower blood levels of liver enzymes and TBA and reduced hepatic inflammation, ductular reaction, and fibrosis. It is possible that the level of NRF2 activation could have been in part involved in the difference between the $\operatorname{Atg} 5^{\Delta \text { hep }}$ and $\operatorname{Atg} 7^{\Delta \text { hep }}$ mice. Thus the levels of SQSTM1/p62 and $\operatorname{Nad}(\mathrm{p}) \mathrm{h}$ quinone dehydrogenase 1 were higher in the $\operatorname{Atg} 7^{\Delta \text { hep }}$ livers than in the Atg $5^{\Delta \text { hep }}$ livers (Figure 3, B and C, and Figure 4, B and C). The extent of Nrf2 activation may determine the severity of endogenous injury, ${ }^{41,48,56}$ which in turn may affect the response to alcohol treatment.

These results demonstrate that the outcomes of the interaction of alcohol and hepatic autophagy function could depend on how autophagy function is disabled (constitutively or acutely), which autophagy gene is deleted (Atg7 or $A \operatorname{tg} 5$ ), and how alcohol is administered. However, published and current results clearly demonstrate that acute inactivation of autophagy or lysosome function, via a genetic, chemical (siRNA), or pharmacologic approach, promotes alcohol-induced liver injury in a variety of alcohol-administration models with different dosages and durations. But the more complex findings of alcohol-induced phenotypes in chronically autophagydeficient mice perhaps more realistically reflect clinical scenarios in which autophagy functions could be compromised through a more chronic process by alcohol and other coexisting factors such as viral infection ${ }^{16-19}$ or a high-fat diet. ${ }^{13-15}$

Variable Liver Pathology in $\operatorname{Atg} 5^{\Delta \text { hep }}$ and $A \operatorname{tg} 7^{\Delta \text { hep }}$ Mice and Their Differential Responses to Alcohol Given through Different Regimens

Embryonic deletion of Atg5 or Atg7 in the parenchymal cells under the albumin promotor leads to severe liver pathology. ${ }^{48,56}$ Both $\operatorname{Atg} 7$ and Atg5 are crucial for LC3 to conjugate to phosphatidylalcoholamine on the autophagosomal membrane, which is required for autophagosome formation. However, the hepatic phenotypes of $\operatorname{Atg} 5^{\Delta \text { hep }}$ and $\operatorname{Atg} 7^{\Delta \text { hep }}$ mice are interestingly different in the degree and progression of the injury. Overall, Atg $5^{\Delta \text { hep }}$ mice seemed to present a less severe phenotype of liver injury (Figure 1, B and C). Similar observations could be found in earlier sudies. ${ }^{48,56}$ In addition, Atg5-deficient mice seem to undergo a spontaneous improvement when they became older (4 months and beyond) (Figure 4, F-H) ${ }^{56}$ Also, the improvement was mainly contributed by the male mice 
(Supplemental Figure S4A), not the female mice (Supplemental Figure S5A). The mechanisms for the more severe phenotype of $\operatorname{Atg} 7^{\mathrm{\Delta hep}}$ mice are not clear, but may be related to the more crucial function of $\operatorname{Atg} 7$ being the only E1-like molecule involved in both Atg5-Atg12 conjugation and LC3-phosphatidylalcoholamine conjugation. ${ }^{5}$ Alternatively, the possibility that $\operatorname{Atg} 7$ might have additional functions cannot be ruled out.

The mild liver injury associated with Atg5 deficiency could have allowed the detection of the added alcoholinduced insults in the acute binge model (Figure 1B). On the other hand, $\operatorname{Atg} 7^{\Delta \text { hep }}$ mice might have had a blunted response to an acute alcohol binge and failed to show an increased injury. Since the elevation of hepatic TG level is an immediate consequence of alcohol stimulation and steatosis is a major pathologic phenomenon in AFLD, ${ }^{46,47}$ the change in the hepatic total TG level was examined in $\operatorname{Atg} 7^{\Delta \text { hep }}$ and $\operatorname{Atg} 5^{\Delta \text { hep }}$ mice. Indeed, TG level was not elevated in $\mathrm{Atg} 7^{\mathrm{\Delta hep}}$ mice (Figure 1C) but was elevated in $\operatorname{Atg} 5^{\Delta \text { hep }}$ (Figure 1B) mice receiving an acute binge treatment. This observation supports that $\operatorname{Atg} 7^{\Delta \text { hep }}$ mice had a blunted response to acute alcohol stimulation. In the chronic-plus-binge regimen, $\operatorname{Atg} 7^{\text {hhep }}$ mice responded to the prolonged alcohol stimulation since the total TG level was elevated (Figure 3E), and consequently an elevated injury was observed (Figure 3D).

The response of $\operatorname{Atg} 5^{\Delta \text { hep }}$ mice to the chronic-plus-binge treatment was unexpected. The liver injury phenotype was paradoxically reduced in these mice despite that they seemed to respond to alcohol as evidenced by elevated hepatic TG level (Figure 4, I and J). The improvement in liver injury despite an elevation in hepatic TG was evident in both sexes and regardless of age (Supplemental Figures S4 and S5). An earlier study had also shown that $\operatorname{Atg} 5^{\Delta \text { hep }}$ mice were paradoxically resistant to acetaminophen-induced liver injury. ${ }^{57}$ A common feature of alcohol- and acetaminophen-induced liver injury is the induction of oxidative stress. Thus it is possible that $\operatorname{Atg} 5^{\Delta \text { hep }}$ mice had pathologic changes that rendered them resistant to oxidative stress.

The deletion of either Atg5 or Atg7 in the liver causes SQSTM1/p62 accumulation in the liver, which in turn activates NRF2. ${ }^{40,41,56,58}$ The latter may create a somewhat reduced environment to resist damage caused by oxidative stress. ${ }^{57}$ However, the elevated NRF2 activation in autophagy deficiency is likely correlated with the pathology, as shown by the co-deletion of $N r f 2$ and the ensuing blockage of most of the liver phenotypes in $\operatorname{Atg} 7^{\Delta \text { hep }}$ and $\operatorname{Atg} 5^{\Delta \text { hep }}$ mice. ${ }^{41,48,56}$ Thus the improved hepatic presentation of Atg $5^{\Delta \text { hep }}$ mice given chronic-plus-binge alcohol treatment may have been due to other factors.

The effect of alcohol in mice with chronic liver injury due to autophagy deficiency is thus complicated by the baseline liver changes in the autophagy-deficient condition. Caution must be exercised in reaching conclusions on the potential mechanisms that are involved. Notably, clinically ALD is often complicated by other conditions such as viral infection $^{16-19}$ and NAFLD, ${ }^{13-15}$ both of which could compromise autophagy function. Long-term alcohol use can also suppress autophagy by itself. ${ }^{9-12,15}$ The findings from this study demonstrate that the effects of alcohol can be quite diverse in livers with varying degrees of autophagy deficiency.

\section{Potential Multiple Factors in Improvement of Liver Injury in $A \operatorname{tg} 5^{\Delta \text { hep }}$ Mice by Chronic Alcohol Treatment}

Other factors to consider include the potential role of inflammation, which is known to play important roles in the pathogenesis of ALFD. ${ }^{49,50}$ The reduced injury in Atg $5^{\Delta \text { hep }}$ livers by the chronic alcohol treatment may have been related to reduced inflammation. In addition, changes related to the metabolism of bile acids and alcohol itself may deserve attention as well.

As previously published, ${ }^{52,56} \mathrm{Atg} 5^{\mathrm{\Delta hep}}$ and $\operatorname{Atg} 7^{\Delta \text { hep }}$ mice develop cholestatic injury, which is accompanied by an increased level of cytokeratin-19-positive ductular cells (ductular reaction), altered mRNA levels of genes in the bile acid-metabolism pathways, and an increase in circulating TBA level. Interestingly, several studies have shown a relationship between alcohol administration and bile acid metabolism. ${ }^{59-61}$ Indeed, serum levels of TBA were decreased by alcohol treatment in both $\operatorname{Atg} 5^{\mathrm{F} / \mathrm{F}}$ and $\operatorname{Atg} 5^{\Delta \text { hep }}$ mice. However, the improving effect in $\operatorname{Atg} 5^{\Delta \text { hep }}$ mice by alcohol may not have been related to intrahepatic bile acid metabolism since the hepatic bile acid level in $\operatorname{Atg} 5^{\Delta \text { hep }}$ remained high (Figure 6, D and E) and the expression of genes that are related to bile acid metabolism did not change significantly (Supplemental Figure S9). Nonetheless, this reduction in serum TBA may still be beneficial, as suggested by the decrease in ductular reaction (Figure 6A) and serum ALT/AST (Figure 4, F-G). How chronic alcohol treatment and Atg5 deficiency lead to improved cholestatic outcome is an interesting topic for future studies.

Alcohol is generally metabolized in hepatic parenchymal cells, which express the highest levels of alcohol-oxidizing enzymes, including ADHs, CYP2E1, and catalase. ${ }^{46}$ The first step of alcohol breakdown in the liver by these enzymes generates toxic metabolites, including acetaldehyde and other potentially damaging molecules. ${ }^{53}$ Interestingly, the mRNA levels of the Adh, Cyp2el, and Cat genes were decreased in Atg5-deficient livers. Reduced levels of these alcohol-oxidizing enzymes may reduce the generation of toxic metabolites, and thus less or no alcohol-mediated toxicity. However, there was no consistent difference in the expression of these genes between $\operatorname{Atg} 5^{\text {thep }}$ livers and $\operatorname{Atg} 7^{\Delta \text { hep }}$ livers (data not shown), which may thus not account for the difference in how these mice responded to alcohol.

The toxic acetaldehyde can be enzymatically removed by ALDH. Aldh2 is one of the most important Aldh family of genes for alcohol metabolism. In other studies in mice, the pharmacologic activation of either Aldh2 or global Aldh2 overexpression seemed to ameliorate chronic alcohol- 
induced hepatic steatosis and improved ALD, ${ }^{62,63}$ and Aldh2 deficiency paradoxically resulted in improved alcoholic fatty livers, although worse liver inflammation and fibrosis. ${ }^{64}$ In the present study, the expression levels of several Aldh genes, including Aldh2, were decreased in Atg5-deficient livers, although the protein levels remained unchanged. The significance of these changes is not known, but the overall findings would suggest that alcohol metabolism might have been altered in $\operatorname{Atg} 5^{\Delta \text { hep }}$ livers, which may have contributed to the observed phenotypes.

A lower expression of these enzymes may result in a slower blood alcohol clearance, as in Adhl and Adh4 knockout mice. ${ }^{65}$ Surprisingly, a faster clearance rate of plasma alcohol in $\operatorname{Atg} 5^{\Delta \text { hep }}$ mice was observed. It is notable that alcohol could be cleared from circulation by other mechanisms independent of these enzymes, such as through breath. The potential involvement of these independent mechanisms needs to be investigated in the future.

In summary, the findings from this study demonstrate a protective role of autophagy in alcohol-induced liver injury, which was best illustrated in models in which an autophagy gene $\operatorname{Atg} 7$ was acutely deleted. In mice with constitutive deletion of Atg7 or Atg5, the effects of autophagy deficiency on alcohol-induced liver phenotype become complicated, in large part due to the coexistence of liver pathology caused by autophagy deficiency. Collectively, the findings from this study indicate the complexity of the relationship between autophagy status and alcohol-induced liver injury. This relationship may be dictated by the timing of the autophagy inhibition and alcohol exposure, the regimen of alcohol administration, and the particular autophagy-related gene being inactivated. These conditions may draw some similarities to the clinical ALDs, which are often complicated by additional confounding factors, such as viral infection ${ }^{16-19}$ and NAFLD, ${ }^{13-15}$ in which autophagy function can be compromised. This study may provide a model to understand the complex interactions of alcohol with autophagy deficiency at various degrees caused by other underlying conditions.

\section{Supplemental Data}

Supplemental material for this article can be found at http://doi.org/10.1016/j.ajpath.2019.05.011.

\section{References}

1. Abdel-Misih SR, Bloomston M: Liver anatomy. Surg Clin North Am 2010, 90:643-653

2. Reddy JK, Rao MS: Lipid metabolism and liver inflammation. II. Fatty liver disease and fatty acid oxidation. Am J Physiol Gastrointest Liver Physiol 2006, 290:G852-G858

3. Deter RL, De Duve C: Influence of glucagon, an inducer of cellular autophagy, on some physical properties of rat liver lysosomes. J Cell Biol 1967, 33:437-449

4. Meijer AJ, Codogno P: Regulation and role of autophagy in mammalian cells. Int J Biochem Cell Biol 2004, 36:2445-2462
5. Mizushima N, Komatsu M: Autophagy: renovation of cells and tissues. Cell 2011, 147:728-741

6. Yin XM, Ding WX, Gao W: Autophagy in the liver. Hepatology 2008, 47:1773-1785

7. Czaja MJ, Ding WX, Donohue TM Jr, Friedman SL, Kim JS, Komatsu M, Lemasters JJ, Lemoine A, Lin JD, Ou JH, Perlmutter DH, Randall G, Ray RB, Tsung A, Yin XM: Functions of autophagy in normal and diseased liver. Autophagy 2013, 9: $1131-1158$

8. Ding WX, Li M, Chen X, Ni HM, Lin CW, Gao W, Lu B, Stolz DB, Clemens DL, Yin XM: Autophagy reduces acute ethanol-induced hepatotoxicity and steatosis in mice. Gastroenterology 2010, 139: $1740-1752$

9. Thomes PG, Trambly CS, Thiele GM, Duryee MJ, Fox HS, Haorah J, Donohue TM Jr: Proteasome activity and autophagosome content in liver are reciprocally regulated by ethanol treatment. Biochem Biophys Res Commun 2012, 417:262-267

10. Kharbanda KK, McVicker DL, Zetterman RK, Donohue TM Jr: Ethanol consumption alters trafficking of lysosomal enzymes and affects the processing of procathepsin $\mathrm{L}$ in rat liver. Biochim Biophys Acta 1996, 1291:45-52

11. Dolganiuc A, Thomes PG, Ding WX, Lemasters JJ, Donohue TM Jr: Autophagy in alcohol-induced liver diseases. Alcohol Clin Exp Res 2012, 36:1301-1308

12. Chao X, Wang S, Zhao K, Li Y, Williams JA, Li T, Chavan H, Krishnamurthy P, He XC, Li L, Ballabio A, Ni HM, Ding WX: Impaired TFEB-mediated lysosome biogenesis and autophagy promote chronic ethanol-induced liver injury and steatosis in mice. Gastroenterology 2018, 155:865-879.e12

13. Yang L, Li P, Fu S, Calay ES, Hotamisligil GS: Defective hepatic autophagy in obesity promotes ER stress and causes insulin resistance. Cell Metab 2010, 11:467-478

14. Zhang H, Yan S, Khambu B, Ma F, Li Y, Chen X, Martina JA, Puertollano R, Li Y, Chalasani N, Yin XM: Dynamic MTORC1-TFEB feedback signaling regulates hepatic autophagy, steatosis and liver injury in long-term nutrient oversupply. Autophagy 2018, 14:1779-1795

15. Lin CW, Zhang H, Li M, Xiong X, Chen X, Chen X, Dong XC, Yin XM: Pharmacological promotion of autophagy alleviates steatosis and injury in alcoholic and non-alcoholic fatty liver conditions in mice. J Hepatol 2013, 58:993-999

16. Tang H, Da L, Mao Y, Li Y, Li D, Xu Z, Li F, Wang Y, Tiollais P, Li T, Zhao M: Hepatitis B virus $\mathrm{X}$ protein sensitizes cells to starvation-induced autophagy via up-regulation of beclin 1 expression. Hepatology 2009, 49:60-71

17. Liu B, Fang M, Hu Y, Huang B, Li N, Chang C, Huang R, Xu X, Yang Z, Chen Z, Liu W: Hepatitis B virus X protein inhibits autophagic degradation by impairing lysosomal maturation. Autophagy 2014, 10:416-430

18. Sir D, Chen WL, Choi J, Wakita T, Yen TS, Ou JH: Induction of incomplete autophagic response by hepatitis $\mathrm{C}$ virus via the unfolded protein response. Hepatology 2008, 48:1054-1061

19. Kim SJ, Khan M, Quan J, Till A, Subramani S, Siddiqui A: Hepatitis B virus disrupts mitochondrial dynamics: induces fission and mitophagy to attenuate apoptosis. PLoS Pathogens 2013, 9:e1003722

20. Lumeng L, Crabb DW: Alcoholic liver disease. Curr Opin Gastroenterol 2000, 16:208-218

21. Lieber CS: Alcoholic fatty liver: its pathogenesis and mechanism of progression to inflammation and fibrosis. Alcohol 2004, 34:9-19

22. Zakhari S, Li TK: Determinants of alcohol use and abuse: impact of quantity and frequency patterns on liver disease. Hepatology 2007, 46:2032-2039

23. Bailey SM, Cunningham CC: Contribution of mitochondria to oxidative stress associated with alcoholic liver disease. Free Radic Biol Med 2002, 32:11-16

24. Demeilliers C, Maisonneuve C, Grodet A, Mansouri A, Nguyen R, Tinel M, Letteron P, Degott C, Feldmann G, Pessayre D, Fromenty B: Impaired adaptive resynthesis and prolonged depletion of hepatic 
mitochondrial DNA after repeated alcohol binges in mice. Gastroenterology 2002, 123:1278-1290

25. Mansouri A, Demeilliers C, Amsellem S, Pessayre D, Fromenty B: Acute ethanol administration oxidatively damages and depletes mitochondrial DNA in mouse liver, brain, heart, and skeletal muscles: protective effects of antioxidants. J Pharmacol Exp Ther 2001, 298: $737-743$

26. Mansouri A, Gaou I, De Kerguenec C, Amsellem S, Haouzi D, Berson A, Moreau A, Feldmann G, Letteron P, Pessayre D, Fromenty B: An alcoholic binge causes massive degradation of hepatic mitochondrial DNA in mice. Gastroenterology 1999, 117: 181-190

27. Cahill A, Cunningham CC, Adachi M, Ishii H, Bailey SM, Fromenty B, Davies A: Effects of alcohol and oxidative stress on liver pathology: the role of the mitochondrion. Alcohol Clin Exp Res 2002, 26:907-915

28. Cahill A, Stabley GJ, Wang X, Hoek JB: Chronic ethanol consumption causes alterations in the structural integrity of mitochondrial DNA in aged rats. Hepatology 1999, 30:881-888

29. Wang L, Khambu B, Zhang H, Yin XM: Autophagy in alcoholic liver disease, self-eating triggered by drinking. Clin Res Hepatol Gastroenterol 2015, 39 Suppl 1:S2-S6

30. Wang L, Zhou J, Yan S, Lei G, Lee CH, Yin XM: Ethanol-triggered lipophagy requires SQSTM1 in AML12 hepatic cells. Sci Rep 2017, 7:12307

31. Thomes PG, Ehlers RA, Trambly CS, Clemens DL, Fox HS, Tuma DJ, Donohue TM: Multilevel regulation of autophagosome content by ethanol oxidation in HepG2 cells. Autophagy 2013, 9:63-73

32. Wu D, Wang X, Zhou R, Yang L, Cederbaum AI: Alcohol steatosis and cytotoxicity: the role of cytochrome P4502E1 and autophagy. Free Radic Biol Med 2012, 53:1346-1357

33. Sid B, Verrax J, Calderon PB: Role of AMPK activation in oxidative cell damage: implications for alcohol-induced liver disease. Biochem Pharmacol 2013, 86:200-209

34. Ding WX, Li M, Yin XM: Selective taste of ethanol-induced autophagy for mitochondria and lipid droplets. Autophagy 2011, 7: 248-249

35. Ni HM, Du K, You M, Ding WX: Critical role of FoxO3a in alcoholinduced autophagy and hepatotoxicity. Am J Pathol 2013, 183: $1815-1825$

36. Ding WX, Yin XM: Sorting, recognition and activation of the misfolded protein degradation pathways through macroautophagy and the proteasome. Autophagy 2008, 4:141-150

37. Ding WX, Ni HM, Gao W, Yoshimori T, Stolz DB, Ron D, Yin XM: Linking of autophagy to ubiquitin-proteasome system is important for the regulation of endoplasmic reticulum stress and cell viability. Am J Pathol 2007, 171:513-524

38. Liuzzi JP, Yoo C: Role of zinc in the regulation of autophagy during ethanol exposure in human hepatoma cells. Biol Trace Elem Res 2013, 156:350-356

39. Kharbanda KK, McVicker DL, Zetterman RK, MacDonald RG, Donohue TM Jr: Flow cytometric analysis of vesicular $\mathrm{pH}$ in rat hepatocytes after ethanol administration. Hepatology 1997, 26: 929-934

40. Takamura A, Komatsu M, Hara T, Sakamoto A, Kishi C, Waguri S, Eishi Y, Hino O, Tanaka K, Mizushima N: Autophagydeficient mice develop multiple liver tumors. Genes Dev 2011, 25 : 795-800

41. Komatsu M, Kurokawa H, Waguri S, Taguchi K, Kobayashi A, Ichimura Y, Sou YS, Ueno I, Sakamoto A, Tong KI, Kim M, Nishito $\mathrm{Y}$, Iemura $\mathrm{S}$, Natsume $\mathrm{T}$, Ueno $\mathrm{T}$, Kominami $\mathrm{E}$, Motohashi H, Tanaka K, Yamamoto M: The selective autophagy substrate p62 activates the stress responsive transcription factor $\mathrm{Nrf} 2$ through inactivation of Keap1. Nat Cell Biol 2010, 12:213-223

42. Schuler M, Dierich A, Chambon P, Metzger D: Efficient temporally controlled targeted somatic mutagenesis in hepatocytes of the mouse. Genesis 2004, 39:167-172
43. Bertola A, Mathews S, Ki SH, Wang H, Gao B: Mouse model of chronic and binge ethanol feeding (the NIAAA model). Nat Protoc 2013, 8:627-637

44. Hu M, Yin H, Mitra MS, Liang X, Ajmo JM, Nadra K, Chrast R, Finck BN, You M: Hepatic-specific lipin-1 deficiency exacerbates experimental alcohol-induced steatohepatitis in mice. Hepatology 2013, 58:1953-1963

45. Wieser V, Tymoszuk P, Adolph TE, Grander C, Grabherr F, Enrich B, Pfister A, Lichtmanegger L, Gerner R, Drach M, Moser P, Zoller H, Weiss G, Moschen AR, Theurl I, Tilg H: Lipocalin 2 drives neutrophilic inflammation in alcoholic liver disease. J Hepatol 2016, 64:872-880

46. Osna NA, Donohue TM, Kharbanda KK: Alcoholic liver disease: pathogenesis and current management. Alcohol Res 2017, 38: $147-161$

47. Sozio M, Crabb DW: Alcohol and lipid metabolism. Am J Physiol Endocrinol Metab 2008, 295:E10-E16

48. Khambu B, Huda N, Chen X, Antoine DJ, Li Y, Dai G, Kohler UA, Zong WX, Waguri S, Werner S, Oury TD, Dong Z, Yin XM: HMGB1 promotes ductular reaction and tumorigenesis in autophagydeficient livers. J Clin Invest 2018, 128:2419-2435

49. Wang HJ, Gao B, Zakhari S, Nagy LE: Inflammation in alcoholic liver disease. Annu Rev Nutr 2012, 32:343-368

50. Degre D, Lemmers A, Gustot T, Ouziel R, Trepo E, Demetter P, Verset L, Quertinmont E, Vercruysse V, Le Moine O, Deviere J, Moreno C: Hepatic expression of CCL2 in alcoholic liver disease is associated with disease severity and neutrophil infiltrates. Clin Exp Immunol 2012, 169:302-310

51. Yamada K, Mizukoshi E, Seike T, Horii R, Kitahara M, Sunagozaka H, Arai K, Yamashita T, Honda M, Kaneko S: Light alcohol consumption has the potential to suppress hepatocellular injury and liver fibrosis in non-alcoholic fatty liver disease. PLoS One 2018, 13:e0191026

52. Khambu B, Li T, Yan S, Yu C, Chen X, Goheen M, Li Y, Lin J, Cummings OW, Lee YA, Friedman S, Dong Z, Feng GS, Wu S, Yin XM: Hepatic autophagy deficiency compromises FXR functionality and causes cholestatic injury. Hepatology 2019, 69: 2196-2213

53. Lieber CS: Relationships between nutrition, alcohol use, and liver disease. Alcohol Res Health 2003, 27:220-231

54. Roberts BJ, Song BJ, Soh Y, Park SS, Shoaf SE: Ethanol induces CYP2E1 by protein stabilization. Role of ubiquitin conjugation in the rapid degradation of CYP2E1. J Biol Chem 1995, 270: 29632-29635

55. Ueno A, Lazaro R, Wang PY, Higashiyama R, Machida K, Tsukamoto H: Mouse intragastric infusion (iG) model. Nat Protoc 2012, 7:771-781

56. Ni HM, Woolbright BL, Williams J, Copple B, Cui W, Luyendyk JP, Jaeschke H, Ding WX: Nrf2 promotes the development of fibrosis and tumorigenesis in mice with defective hepatic autophagy. J Hepatol 2014, 61:617-625

57. Ni HM, Boggess N, McGill MR, Lebofsky M, Borude P, Apte U, Jaeschke H, Ding WX: Liver-specific loss of Atg5 causes persistent activation of $\mathrm{Nrf} 2$ and protects against acetaminophen-induced liver injury. Toxicol Sci 2012, 127:438-450

58. Komatsu M, Waguri S, Ueno T, Iwata J, Murata S, Tanida I, Ezaki J, Mizushima N, Ohsumi Y, Uchiyama Y, Kominami E, Tanaka K, Chiba T: Impairment of starvation-induced and constitutive autophagy in Atg7-deficient mice. J Cell Biol 2005, 169:425-434

59. Hartmann P, Hochrath K, Horvath A, Chen P, Seebauer CT, Llorente C, Wang L, Alnouti Y, Fouts DE, Starkel P, Loomba R, Coulter S, Liddle C, Yu RT, Ling L, Rossi SJ, DePaoli AM, Downes M, Evans RM, Brenner DA, Schnabl B: Modulation of the intestinal bile acid/farnesoid $\mathrm{X}$ receptor/fibroblast growth factor 15 axis improves alcoholic liver disease in mice. Hepatology 2018, 67:2150-2166

60. Hu X, Jogasuria A, Wang J, Kim C, Han Y, Shen H, Wu J, You M: MitoNEET deficiency alleviates experimental alcoholic 
steatohepatitis in mice by stimulating endocrine adiponectin-Fgf15 axis. J Biol Chem 2016, 291:22482-22495

61. Wang J, Kim C, Jogasuria A, Han Y, Hu X, Wu J, Shen H, Chrast R, Finck BN, You M: Myeloid cell-specific lipin-1 deficiency stimulates endocrine adiponectin-FGF15 axis and ameliorates ethanol-induced liver injury in mice. Sci Rep 2016, 6:34117

62. Zhong W, Zhang W, Li Q, Xie G, Sun Q, Sun X, Tan X, Sun X, Jia W, Zhou Z: Pharmacological activation of aldehyde dehydrogenase 2 by Alda- 1 reverses alcohol- induced hepatic steatosis and cell death in mice. J Hepatol 2015, 62:1375-1381

63. Guo R, Xu X, Babcock SA, Zhang Y, Ren J: Aldehyde dedydrogenase-2 plays a beneficial role in ameliorating chronic alcohol-induced hepatic steatosis and inflammation through regulation of autophagy. J Hepatol 2015, 62:647-656

64. Kwon HJ, Won YS, Park O, Chang BX, Duryee MJ, Thiele GE, Matsumoto A, Singh S, Abdelmegeed MA, Song BJ, Kawamoto T, Vasiliou V, Thiele GM, Gao B: Aldehyde dehydrogenase 2 deficiency ameliorates alcoholic fatty liver but worsens liver inflammation and fibrosis in mice. Hepatology 2014, 60:146-157

65. Deltour L, Foglio MH, Duester G: Metabolic deficiencies in alcohol dehydrogenase Adh1, Adh3, and Adh4 null mutant mice. Overlapping roles of Adh1 and Adh4 in ethanol clearance and metabolism of retinol to retinoic acid. J Biol Chem 1999, 274: 16796-16801 